\title{
Litter to glitter: promoting herbaceous groundcover and diversity in mid-southern USA oak forests using canopy disturbance and fire
}

Andrew L. Vander Yacht ${ }^{1 *}$ (D), Patrick D. Keyser ${ }^{2}$, Seth A. Barrioz ${ }^{2}$, Charles Kwit ${ }^{3}$, Michael C. Stambaugh ${ }^{4}$, Wayne K. Clatterbuck ${ }^{3}$ and Ryan Jacobs ${ }^{5}$

\begin{abstract}
Background: In oak-dominated communities throughout eastern North America, fire exclusion and subsequent woody encroachment has replaced the "glitter" of once robust and diverse wildflower and grass layers with leaflitter dominance. Restoring the important herbaceous components of Eastern oak ecosystems could involve pairing heavy canopy disturbance with growing-season fire, but potential negative effects warrant research. Beginning with 20 ha replicates of closed-canopy forest at three sites across Tennessee and North Carolina, USA, we monitored groundcover response to combinations of thinning (none; light: $14 \mathrm{~m}^{2}$ ha ${ }^{-1}$ residual basal area; and heavy: $7 \mathrm{~m}^{2}$ ha ${ }^{-1}$ ) and seasonal fire (none; March: pre leaf expansion; and October: pre leaf abscission) from 2008 to 2016.

Results: Before treatments, woody plants and leaf-litter-dominated groundcover and herbaceous plants were rare ( $<6 \%$ groundcover, 118 species). By 2016, herbaceous groundcover averaged 59\% after heavy thinning and three biennial burns, and 359 herbaceous species were documented. Only 6\% (23) of these species appeared negatively affected by applied disturbances. Across sites, thin-and-burn treatments increased graminoid groundcover 14-fold, forb groundcover 50-fold, herbaceous richness 9-fold, and herbaceous diversity 10-fold, relative to unmanaged stands. These increases were often greater where fire was repeatedly applied, and only after repeated fire was herbaceous response greater in heavily thinned stands relative to lightly thinned stands. Burn-only treatments rarely affected herbaceous metrics, and thin-and-burn treatments more than doubled woody groundcover. This suggests that canopy reduction, leaf-litter consumption, and pulses of bare ground were more related to positive herbaceous responses than to the control of woody competition in the understory. Fire season effects were not observed, but herbaceous response after less intense October fires was comparable to that following more intense March fires.

(Continued on next page)
\end{abstract}

\footnotetext{
* Correspondence: vandery1@msu.edu

'Department of Forestry, Michigan State University, Natural Resources

Building, 480 Wilson Road, Room 126, East Lansing, Michigan 48824-6402,

USA

Full list of author information is available at the end of the article
}

Springer Open

(c) The Author(s). 2020 Open Access This article is licensed under a Creative Commons Attribution 4.0 International License, which permits use, sharing, adaptation, distribution and reproduction in any medium or format, as long as you give appropriate credit to the original author(s) and the source, provide a link to the Creative Commons licence, and indicate if changes were made. The images or other third party material in this article are included in the article's Creative Commons licence, unless indicated otherwise in a credit line to the material. If material is not included in the article's Creative Commons licence and your intended use is not permitted by statutory regulation or exceeds the permitted use, you will need to obtain permission directly from the copyright holder. To view a copy of this licence, visit http://creativecommons.org/licenses/by/4.0/. 
(Continued from previous page)

Conclusions: Our results conflict with warnings concerning the potential negative effects of disturbance on herbaceous diversity east of the prairie-woodland transition zone. Canopy disturbance and repeated fire, regardless of season, widely restored herbaceous groundcover and diversity in Eastern oak ecosystems. Herbaceous components were resilient to extended periods of fire exclusion, but current conservation programs often prioritize existing, highquality sites. Our results suggest that such policies may overlook the tremendous restoration potential present in otherwise inconspicuous understories of closed-canopy oak forests throughout eastern North America.

Keywords: canopy disturbance, fire season, herbaceous groundcover, mesophication, North Carolina, restoration, savanna, Tennessee, woodland, woody encroachment

\section{Resumen}

Antecedentes: En comunidades dominadas por robles en todo el este de Norteamérica, la exclusión del fuego y la subsecuente invasión de arbustivas, ha reemplazado el esplendor de antaño de estratos robustos y diversos de flores silvestres y pastos dominantes del tipo hojas-broza. Restaurar los importantes componentes herbáceos de los ecosistemas de roble del este de Norteamérica puede involucrar el acoplar un fuerte disturbio del dosel con quemas durante la estación de fuego, aunque los potenciales efectos negativos de estas prácticas justifican su investigación. Comenzando con 20 réplicas de bosques con doseles cerrados en tres sitios a través de Tennessee y Carolina del Norte, EEUU, monitoreamos la respuesta de la cobertura del suelo a combinaciones de raleos (ninguno; suave: $14 \mathrm{~m}^{2} \mathrm{ha}^{-1}$ de área basal residual; y fuerte: $7 \mathrm{~m}^{2} \mathrm{ha}^{-1}$ ), y fuegos estacionales (ninguno; en marzo: pre expansión foliar; y octubre: pre absición foliar), desde 2008 a 2016.

Resultados: Antes de los tratamientos, las plantas leñosas y la cobertura de suelo dominada por especies de hojasbroza fueron raras (<6\% de cobertura de suelo, 118 especies). En 2016, la cobertura de suelo por herbáceas promedió el 59\% y se documentaron 359 especies después de un raleo fuerte y tres quemas bienales. Solo el 6\% (23) de esas especies parecieron ser afectadas por los disturbios aplicados. A través de los sitios, los tratamientos de raleo y quema incrementaron 14 veces la cobertura de graminoides, 50 veces la cobertura de hierbas de hoja ancha, 9 veces la riqueza de herbáceas y 10 veces su diversidad, en relación a rodales no manejados. Estos incrementos fueron frecuentemente mayores cuando las quemas fueron aplicadas repetidamente, y solo luego de quemas repetidas la respuesta de las herbáceas fue mayor en rodales donde los raleos fueron más fuertes en relación a rodales cuyos raleos fueron suaves. Los tratamientos solo de quemas raramente afectaron las mediciones de herbáceas, y la combinación de quema y raleo más que duplicó la cobertura de leñosas. Esto sugiere que la reducción del dosel, el consumo de especies de hoja y broza, y pulsos de suelo desnudo fueron más relacionados a respuestas positivas de herbáceas que al control de la competencia de leñosas en el sotobosque. No fueron observados efectos relacionados con la estación de aplicación de las quemas, aunque la respuesta de herbáceas luego de las quemas menos intensas de octubre fue comparable con aquella que siguió a quemas más intensas en marzo.

Conclusiones: Nuestros resultados colisionan con las advertencias concernientes a los efectos potencialmente negativos de los disturbios sobre la diversidad de herbáceas al este de la zona de transición entre las praderas y los bosques de roble. El disturbio del dosel y quemas repetidas, independientemente de la época de aplicación, restauran abundantemente la cobertura y diversidad de los ecosistemas de robles del este. El componente herbáceo fue resiliente a largos períodos de exclusión del fuego, aunque los programas de conservación corrientes frecuentemente priorizan los sitios actuales de alta calidad. Nuestros resultados sugieren que estas políticas pueden dejar de lado el gran potencial de restauración que tienen los poco llamativos sotobosques que crecen bajo doseles cerrados en los bosques de roble del este de Norteamérica. 


\section{Background}

Oak (Quercus L. spp.) woodlands (30 to 80\% canopy cover) and savannas (10 to 30\% canopy cover) (Nelson 2010) once covered substantial portions of the Appalachian and Central Hardwood regions of eastern North America (hereafter, Mid-South; Nuzzo 1986; DeSelm 1994). Sparse overstories of oaks and other fire-tolerant tree species were created and maintained by frequent fire throughout the region (Fralish et al. 2000; Guyette et al. 2006; Lafon et al. 2017). Such structure distinguished woodlands and savannas from prairies and forests (Faber-Langendoen 2001), and allowed light to reach and promote another defining characteristicrobust and diverse herbaceous ground layers (Taft 1997). Early European explorers of the Mid-South described large herbivore herds grazing on abundant native warm-season grasses, legumes, and other forbs species (Michaux 1805; Ramsey 1853). Understory gradients in plant resources likely radiated outward from the boles of scattered trees (Peterson et al. 2007), promoting levels of herbaceous diversity that exceeded both prairies and forests (DeSelm 1994; Leach and Givnish 1999). Herbaceous ground layers were well adapted to post-fire environments, but also created self-reinforcing feedbacks that maintained such conditions by providing a continuous, well ventilated, and easily ignited fuelbed (Mitchell et al. 2009; Maynard and Brewer 2013).

The "glitter" of robust and diverse herbaceous layers under sparse oak overstories has been transformed into leaf litter throughout the Mid-South. More than 99\% of Midwestern oak savannas have vanished since European settlement (Nuzzo 1986; Noss et al. 1995), and declines farther east are similar (Delcourt et al. 1998; Brewer 2001). Land conversion and development contributed to the decline (Heikens and Robertson 1994), but so did fire exclusion (Abrams 1992; McPherson 1997; Nowacki and Abrams 2015). Fire's absence facilitated succession towards increased canopy closure, greater understory woody encroachment (Briggs et al. 2005), reduced herbaceous groundcover, and disappearance of the plant resource gradients (e.g., moisture, light, nutrients) that sustained herbaceous diversity (Breshears 2006; Brudvig and Asbjornsen 2009). Physical and chemical properties of leaf litter shifted with associated regional increases in the dominance of fire-intolerant woody species to reduce fuelbed flammability (Kreye et al. 2013; Alexander and Arthur 2014; Babl et al. 2020) and, thus, fire's control of woody growth. Dark, moist, and cool micro-environments now dominate forest understories (Nowacki and Abrams 2008) and preclude herbaceous layers (Hutchinson et al. 2005; Barrioz et al. 2013). Removing herbaceous ground layers from Eastern oak ecosystems may have increased susceptibility to invasive species (Knops et al. 1999), encouraged regional declines in pollinators (Hanula et al. 2015) and disturbance-dependent wildlife (Harper et al. 2016; Vander Yacht et al. 2016), and compromised the restoration potential of imperiled oak woodlands and savannas (Noss et al. 1995; Maynard and Brewer 2013).

Fortunately, the disturbances responsible for creating and maintaining these communities can also be used for their restoration (McPherson 1997). Prescribed fire stimulates herbaceous plants by making nutrients available for growth (Scharenbroch et al. 2012) and removing layers of leaf litter that inhibit herbaceous germination (Lashley et al. 2011). Fire is essential for oak woodland and savanna restoration (Peterson and Reich 2001), but is slow to alter overstory characteristics (Knapp et al. 2015). Mechanical canopy disturbance quickly increases the light available for herbaceous germination and growth (Nielsen et al. 2003; Brewer 2016), but also promotes understory woody vegetation (McCord et al. 2014) that limits herbaceous layer development (Lashley et al. 2011; Barrioz et al. 2013). A long-term regimen of biennial fire can suppress woody undergrowth and maximize herbaceous groundcover and richness (Peterson et al. 2007; Peterson and Reich 2008). Thus, restoring herbaceously dominated ground layers is best accomplished using canopy disturbance and fire in conjunction (Lettow et al. 2014).

Techniques for restoring the herbaceous ground layers of oak woodlands and savannas have been well developed outside the Mid-South, but the applicability of such work is limited in the region by differences in climate, length of active fire suppression, and near-absence of remnant reference communities. Attempts to restore oak woodlands (Jackson et al. 2006; McCord et al. 2014) and savannas (Barrioz et al. 2013) in the Mid-South are rare and can promote invasive species that impede restoration goals (Brewer et al. 2015). They also typically proceed from closed-canopy forests characterized by woody undergrowth that often resprouts prolifically after fire (Blankenship and Arthur 2006; Vander Yacht et al. 2017a). Reducing such vegetation requires a long-term commitment to prescribed burning (Hutchinson et al. 2012; Arthur et al. 2015) or expensive herbicide (Vander Yacht et al. 2017b) and mechanical (Lettow et al. 2014) removals. Growing-season fire can result in comparatively greater woody plant mortality and herbaceous layer gains than dormant-season fire (Waldrop et al. 1992; Gruchy et al. 2009; Robertson and Hmielowski 2014), an effect potentially explained by seasonal differences in fire behavior (Vander Yacht et al. 2017a) or root carbohydrate reserves (Huddle and Pallardy 1999). Combining growing-season fire with canopy disturbance could thus accelerate restoration (Knapp et al. 2009), but experimental evaluation is needed in the Mid-South where the seasonal effects of fire on herbaceous 
communities is poorly understood (Gilliam and Roberts 2003) and where growing-season fire may be a departure from historical regimes (Guyette et al. 2006).

Within a replicated experiment at three sites located across the Mid-South, we monitored groundcover response from 2008 to 2016 across combinations of canopy disturbance (none; woodland: thinned to $14 \mathrm{~m}^{2} \mathrm{ha}^{-1}$ residual basal area; or savanna: thinned to $7 \mathrm{~m}^{2} \mathrm{ha}^{-1}$ residual basal area) and season of prescribed fire (none; spring: March, pre leaf expansion; and fall: October, pre leaf abscission). We hypothesized that herbaceous groundcover and diversity response would be greatest in fall-burned savannas relative to other treatments (H1). We also believed that herbaceous response would not differ between burn-only and unmanaged treatments $(\mathrm{H} 2)$; would be greater in thin-and-burn relative to unmanaged treatments $(\mathrm{H} 3)$; would be greater in savannas relative to woodlands (H4); and would be greater after fall burning relative to spring burning (H5). Light-rich environments are important to herbaceous layer development, and late growing-season fire's typically slower rate of spread (Vander Yacht et al. 2017a) and timing in relation to woody plant phenology (Huddle and Pallardy 1999) could potentially reduce understory woody competition and germination inhibiting layers of leaf litter and debris more so than traditional dormant-season fire. To validate this as the driving mechanism behind a potential increase in efficacy of a treatment in promoting herbaceous development, we also monitored changes in woody, leaf litter, debris, and bare (exposed organic or mineral soil) groundcover.

\section{Methods}

\section{Study areas}

Our first site was Catoosa Wildlife Management Area (CWMA), a 32374 ha property managed by the Tennessee Wildlife Resources Agency (TWRA) on the Cumberland Plateau in the Southwestern Appalachians ecoregion (all ecoregions: Level III; US EPA 2013). Broad ridges and dissecting ravines ranged from 437 to $521 \mathrm{~m}$ in elevation. Soils were Mesic Typic Hapludults (Soil Survey Staff NRCS 2014) over weathered sandstone and conglomerate (Nicholson et al. 2005). Annual precipitation and temperature averaged $140 \mathrm{~cm}$ and $13{ }^{\circ} \mathrm{C}$, respectively, from 1981 to 2010 (National Climatic Data Center 2014). Forests were established following abandonment of site's use as cattle rangeland (1947, Coffey 2012) and oaks dominated at study initiation, including white oak (Quercus alba L.), southern red oak (Q. falcata Michx.), black oak (Q. veluntina Lam.), and scarlet oak (Q. coccinea Münchh.). Red maple (Acer rubrum L.), sourwood (Oxydendrum arboreum L.), and hickories (Carya Nutt. spp.) were also abundant. Shortleaf pine (Pinus echinata Mill.) was once common but became a minimal overstory component after the southern pine bark beetle (Dendroctonus frontalis Zimmermann) outbreak of 1999 to 2000 (Coffey 2012). In response, TWRA began using salvage cutting and prescribed fire to manage for oak woodlands and savannas. The site's floral (Barrioz et al. 2013; Vander Yacht et al. 2017a) and faunal (Cox et al. 2016; Vander Yacht et al. 2016) response indicated restoration progress.

Our second site was Green River Game Lands (GRGL), a 5726 ha North Carolina Wildlife Resources Commission (NCWRC) property situated at the interface between the Blue Ridge and Piedmont ecoregions. Narrow ridges and steep ravines ranged from 366 to $640 \mathrm{~m}$ in elevation. Soils were deep $(>1 \mathrm{~m})$, well drained, and mostly in the Evard series (fine loamy, oxidic, Mesic Typic Hapludults; Keenan 1998) over gneiss, schist, and phyllite rock (Clark 2008). Annual precipitation and temperature averaged $139 \mathrm{~cm}$ and $14{ }^{\circ} \mathrm{C}$, respectively, from 1981 to 2010 (National Climatic Data Center 2014). Forests were 80 to 120 years old with no recent disturbances. Forest canopies were also dominated by oaks at study initiation, but chestnut oak (Quercus montana Willd.), northern red oak (Q. rubra L.), yellow poplar (Liriodendron tulipifera L.), and table mountain pine (Pinus pungens Lamb.) were more common relative to other sites. A dense ericaceous understory of mountain laurel (Kalmia latifolia L.), rosebay rhododendron (Rhododendron maximum L.), and other species occurred throughout the site.

Our third site was Land Between the Lakes (LBL), a 68797 ha National Recreation Area in western Kentucky and Tennessee managed by the US Forest Service (USFS) and situated in the Western Highland Rim of the Interior Plateau. Rolling topography, with elevations of 122 to $198 \mathrm{~m}$, were underlain by limestone bedrock. Soil series included Bodine, Baxter and Hammock with loess caps on ridgetops and mid-slopes, dominated by Saffell-Bodine complex, Lax silt loam, Ennis gravelly silt loam, and Bodine and Sengtown (Franklin et al. 2003). Mean precipitation and temperature from 1981 to 2010 were $134 \mathrm{~cm}$ and $14{ }^{\circ} \mathrm{C}$, respectively. Relative to other sites, forest composition lacked a significant pine component, and white oak, chestnut oak, hickories, and post oak (Quercus stellata Wangenh.) were relatively more dominant.

\section{Experimental design and restoration treatments}

We treated sites as independent experiments because of differences in species composition, the timing and type of treatments, and discontinuity of data collection. Treatment implementation and replication differed by site as a result of administrative agency constraints (Table 1). At all sites, 20 ha forested stands were configured to maximize core area and assigned treatments 
Table 1 Number of 20 ha replicates by treatment and site during (2008 to 2016) oak woodland and savanna restoration experiments at Catoosa Wildlife Management Area (Tennessee, USA), Green River Game Lands (North Carolina, USA), and Land Between the Lakes National Recreation Area (Tennessee, USA). Treatments were unmanaged stands, burn only in the spring (Spring only) or fall (Fall only), and combinations of thinning to $14 \mathrm{~m}^{2} \mathrm{ha}^{-1}$ (woodland) or $7 \mathrm{~m}^{2} \mathrm{ha}^{-1}$ (savanna) residual basal area with March (Spring) or October (Fall) fire. Dashes represent the absence of a treatment at a site

\begin{tabular}{|c|c|c|c|c|c|c|c|}
\hline \multirow[b]{2}{*}{ Site } & \multicolumn{7}{|l|}{ Treatment } \\
\hline & Unmanaged & Spring only & Fall only & Spring woodland & Fall woodland & Spring savanna & Fall savanna \\
\hline Catoosa Wildlife Management Area & 2 & - & - & 2 & 2 & 2 & 2 \\
\hline Green River Game Lands & 1 & - & 1 & 1 & 1 & 1 & 1 \\
\hline Land Between the Lakes & 2 & 2 & - & 4 & - & 4 & - \\
\hline
\end{tabular}

randomly. Treatments included: (1) unmanaged stands; (2) burn-only in the spring; (3) burn-only in the fall; (4) thinning to woodland residual basal area $\left(14 \mathrm{~m}^{2} \mathrm{ha}^{-1}\right)$ and spring burning; (5) thinning to woodland residual basal area and fall burning; (6) thinning to savanna residual basal area $\left(7 \mathrm{~m}^{2} \mathrm{ha}^{-1}\right)$ and spring burning; and (7) thinning to savanna residual basal area and fall burning. At LBL, target residual basal area for savannas was greater $\left(9 \mathrm{~m}^{2} \mathrm{ha}^{-1}\right)$ relative to other sites due to US Forest Service administrative constraints. Based on vegetation sampling conducted prior to treatments (explained in data collection), canopy closure averaged $90.7 \%( \pm 2.5 \mathrm{SE})$ and live basal area was $20.1 \mathrm{~m}^{2} \mathrm{ha}^{-1}( \pm 2.0 \mathrm{SE})$. Midstory density (stems $>1.4 \mathrm{~m}$ tall, $<12.7 \mathrm{~cm}$ diameter at breast height $[\mathrm{DBH}])$ descended from east to west
(GRGL: 2423 stems ha ${ }^{-1} \pm 391$ SE; CWMA: 1936 stems ha ${ }^{-1} \pm 182$ SE; LBL: 985 stems ha ${ }^{-1} \pm 219$ SE). Herbaceous groundcover was consistently minimal $(5.7 \% \pm 2.0 \mathrm{SE})$, and ericaceous shrubs, woody regeneration, and litter dominated understories (Vander Yacht et al. 2017a).

Canopy reductions occurred commercially during the dormant season (Fig. 1). Where possible, oaks, hickories, and shortleaf pine were retained while fire-intolerant species including maples (Acer L. spp.), yellow poplar, and sweetgum (Liquidambar styraciflua L.) were removed. After thinning, but before burning, residual basal area and canopy closure was comparable across sites within unmanaged and burn-only treatments $\left(21.4 \mathrm{~m}^{2} \mathrm{ha}^{-1} \pm 1.1 \mathrm{SE}\right.$ and $97.6 \% \pm 0.4 \mathrm{SE}$, respectively),

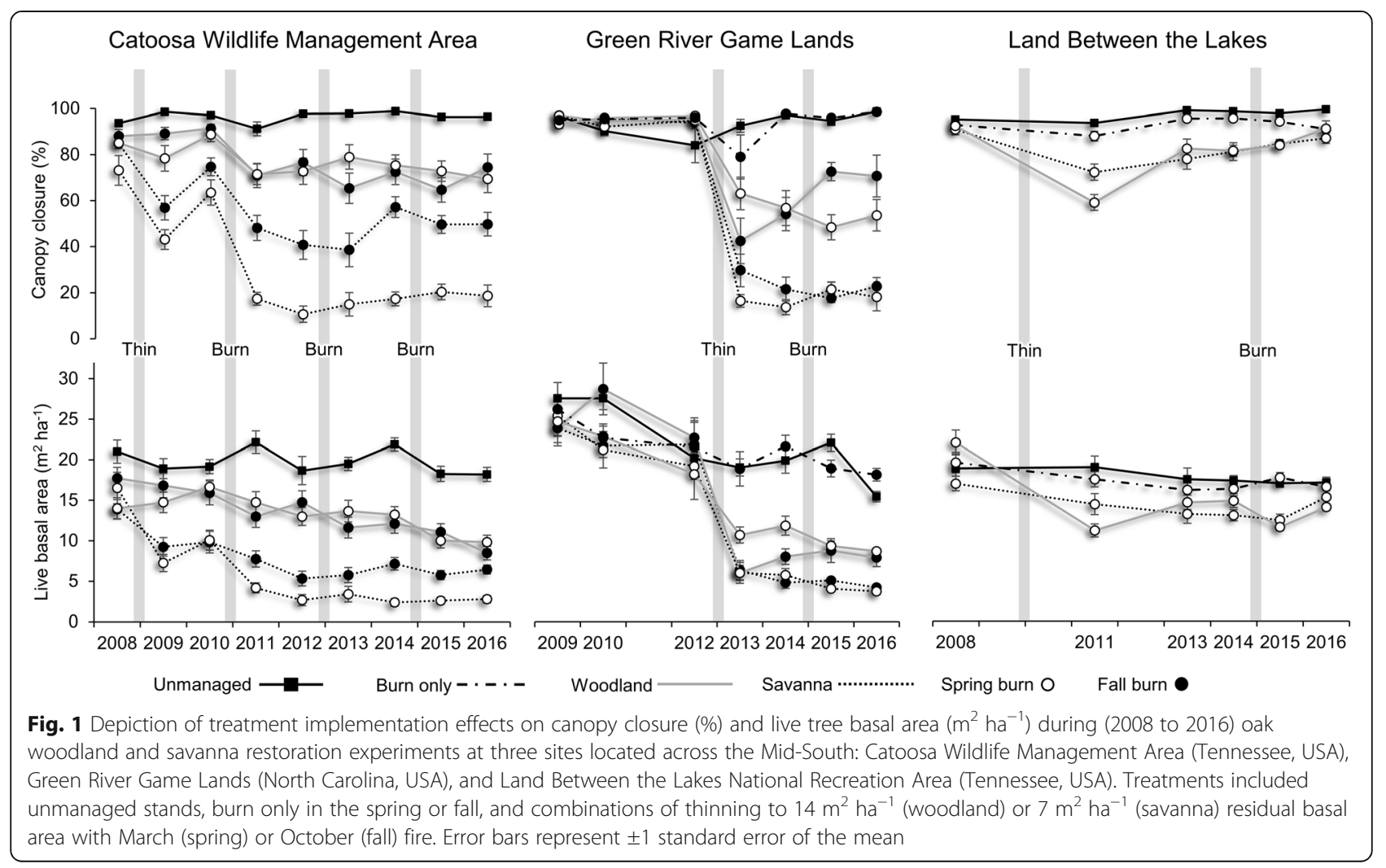


woodlands $\left(14.6 \mathrm{~m}^{2} \mathrm{ha}^{-1} \pm 1.5 \mathrm{SE}\right.$ and $77.7 \% \pm 4.6 \mathrm{SE}$, respectively), and savannas $\left(9.3 \mathrm{~m}^{2} \mathrm{ha}^{-1} \pm 1.6 \mathrm{SE}\right.$ and $53.7 \% \pm 4.2 \mathrm{SE}$, respectively). Ring firing was used at CWMA to burn fall treatments three times in mid October prior to leaf abscission (2010, 2012, and 2014), and spring treatments three times in mid March prior to bud break (2011, 2013, and 2015). At GRGL, similar seasonal timing of fire (October 2015 and March 2016) was applied once using strip-head firing. At LBL, spring fires were conducted in late March 2015 using aerial grid ignition from a helicopter (Fig. 1).

Burning conditions and fire behavior were monitored at all sites following protocols of Vander Yacht et al. (2017a). We determined fine (1-hour and litter) and 10-hour fuel moisture content by oven drying samples, recorded on-site weather, and systematically measured fire spread and flame lengths. We also placed foil-wrapped ceramic tiles $(n=181)$ painted with Tempilaq (LA-CO Industries Inc., Elk Grove Village, Illinois, USA) indicating liquids at $70 \times 70 \mathrm{~m}$ grid intersections within treatment stands. Burn conditions and fire behavior were consistent by season across sites (Additional file 1). Weather conditions were warmer $\left(+7{ }^{\circ} \mathrm{C}\right)$ and fine fuels (litter and 1-hour twigs) were nearly $5 \%$ drier during fall relative to spring burns. However, increased wind speed $\left(+1.9 \mathrm{~m} \mathrm{~s}^{-1}\right)$ during spring fires led to heading fires that were nearly double the rate-of-spread and flame length of those in fall. Tile-recorded temperatures were $40{ }^{\circ} \mathrm{C}$ hotter during spring relative to fall fires.

\section{Sampling design and data collection}

We collected data from 2008 to 2016 in late May through early August. Monitoring did not occur during some years at some sites (Fig. 1). We located permanent plots $\left(n=15\right.$ stand $\left.^{-1}\right)$ at intersections of a $70 \times 70 \mathrm{~m}$ grid within the core (50m buffer) of each stand. At each plot, we established a $50 \mathrm{~m}$ transect running through plot center and perpendicular to landscape slope. We characterized groundcover along this transect at $1 \mathrm{~m}$ intervals using the point-intercept method (Bonham 1989). At each interval, cover below a height of $1.37 \mathrm{~m}$ was categorized as either woody (tree and shrub species), litter, debris (down woody material $>7.6 \mathrm{~cm}$ in diameter), bare (exposed organic or mineral soil), graminoid, forb, or fern. All intersected herbaceous vegetation was identified to species. We calculated percent groundcover for each category as the number of intercepts where a category was present divided by the total number of intercepts (50). We also used data to determine plot-level herbaceous richness and calculate Shannon-Wiener's Index $\left(\mathrm{H}^{\prime}\right.$, Magurran 1988) of diversity. To validate thinning treatments, we measured live tree basal area and canopy closure at the ends and center of each $50 \mathrm{~m}$ transect using a 2-factor metric prism and convex spherical densiometer, respectively. At these same locations within a plot, we also assessed topography by measuring percent slope with a clinometer, aspect with a compass, and assigned a numerical slope position (1-6: alluvial, cove, toe-slope, mid-slope, shoulder, or ridge).

\section{Data analysis}

We conducted all analyses in SAS 9.4 using PROC MIXED (SAS Institute, Cary, North Carolina, USA). For each site and year (2008 to 2016), we calculated standlevel means for all dependent variables, including percent cover of woody plants, litter, debris, bare ground, graminoids, and forbs, as well as herbaceous species richness and diversity. Fern groundcover was never substantial $(1.8 \% \pm 0.2 \mathrm{SE})$ and not individually analyzed. Before modeling, we tested each dependent variable for normality (Shapiro-Wilk's test [Shapiro and Wilk 1965], $\mathrm{W}>0.90$ ), transformed using an arcsin square-root function when necessary, and graphically observed equality of variance. We then developed separate overall (2008 to 2016) and end-result (2016) ANCOVA and ANOVA models for each dependent variable. All models included mixed effects and repeated measures. Fixed effects included treatment, year, and treatment $\times$ year interactions in overall models, and treatment in end-result models. Year was a fixed effect because treatments were applied over time. In all models, replicate $\times$ treatment interactions were a random effect. We initially used Kenward-Roger degree of freedom method (Kenward and Roger 1997), but autoregressive correlations between annual data were ultimately dropped in all models because differences in fit between inclusion and omission were small $(<5,-2$ residual $\log$ likelihood per covariance parameter; Littell et al. 2006). After observing a significant ANCOVA and ANOVA fixed effect, we used least significant difference (LSD) mean separation.

An a priori set of topographical covariates (aspect, slope, and slope position) were also included as fixed effects to correct for their effects on dependent variables across the operational scale (20 ha) of treatments. We worried that variation in these factors-known to influence our groundcover variables-was not distributed equally across delineated stands. Covariates were only retained in models when significant $(\alpha=0.05)$, and this determination occurred independently within overall and end-result models. We used the Beers et al. 1966 transformation to make aspect a continuous variable between 0.00 (southwest) and 2.00 (northeast). Averaging categorically assigned slope positions similarly resulted in a continuous variable. We did not observe collinearity among included covariates $(r<0.6)$, and plots of dependent variable and covariate relationships provided evidence of linear relationships. Tested covariate $\times$ treatment interactions were never significant, supporting 
homogeneity of covariate slopes across treatments. We used a similar method to determine homogeneity of covariate slopes across years. Although some covariates had small partial $r^{2}(\geq 0.15)$, their inclusion decreased Akaike's Information Criterion for small sample size by $\geq 2$ and reduced residual error variance $(\geq 8.2 \%)$.

Within end-result (2016) models, we expected that mean separation might result in difficult to interpret differences across treatments (i.e., gradual transitions with numerous intermediate designations). To support conclusions related to hypotheses $\mathrm{H} 2$ through $\mathrm{H} 5$, we used orthogonal contrasts to test for differences across collapsed treatment categories by site. This included testing for end-result differences between: (1) unmanaged and burn-only treatments; (2) unmanaged and thin-and-burn treatments; (3) burn-only and thin-and-burn treatments; (4) woodlands and savannas; and (5) fall burning versus spring burning. Specific contrasts were only tested at applicable sites (e.g., no burn-only treatment at CWMA). Orthogonal contrasts are independent statistical tests that we interpreted even if LSD mean separation indicated similarity in dependent variables across treatment levels.

To gain a general sense of how individual herbaceous species responded to treatments, we presented total encounters across all years (2008 to 2016) by site and treatment for every herbaceous species documented in our study (Additional file 2). To summarize these data, we compared average encounters in treatments with average encounters in unmanaged stands. We characterized individual species' response to applied treatments by assigning one of four response labels: (1) positive, when average encounters in unmanaged stands were less than average encounters across treatments; (2) negative, when average encounters in unmanaged stands were greater than average encounters across treatments; (3) neutral, when average encounters were equal in unmanaged stands and treatments; and (4) rare, species with $<2$ total encounters during our study.

\section{Results}

\section{Graminoid groundcover}

Before implementing treatments, we encountered 9, 17, and 8 species of graminoids at CWMA, GRGL, and LBL, respectively, and the genera Dichanthelium (Hitchc. \& Chase) Gould and Carex L. were common. By the conclusion of monitoring (2016), we cumulatively documented 71 (CWMA), 47 (GRGL), and 57 (LBL) graminoid species, and only two (Carex hirtifolia Mack. and Carex cephalophora Muhl. ex Willd.) appeared negatively affected by applied disturbances (Additional file 2). Needlegrass (Piptochaetium avenaceum [L.] Parodi) was within the top ten most frequently encountered graminoid species at all sites, and at CWMA was encountered nearly four times as often as the second most common graminoid (Dichanthelium dichotomum [L.] Gould). Across all sites, the genera Carex (25 species), Dichanthelium (13 species), Chasmanthium Link (2 species), and Danthonia DC. (3 species) accounted for many of the most abundant graminoid species. Broomsedge (Andropogon virginicus L.) was also common, and other documented native warm-season grasses included little bluestem (Schizachyrium scoparium [Michx.] Nash), big bluestem (Andropogon gerardii Vitman), Indiangrass (Sorghastrum nutans [L.] Nash), and side-oats grama (Bouteloua curtipendula [Michx.] Torr.). We documented two invasive grasses: Nepalese browntop (Microstegium vimineum [Trin.] A. Camus) occurred at all sites and Chinese silvergrass (Miscanthus sinensis Anderss.) was common at GRGL.

Graminoid groundcover increased more over time in thinned and burned treatments relative to unmanaged stands at all sites (Fig. 2, Tables 2 and 3). At CWMA, graminoid groundcover additionally increased more rapidly over time in savannas relative to woodlands, and a biennial post-fire cycle of decreases in year 1 followed by equal to greater recovery in year 2 was more apparent relative to other sites. Overall increases after three iterations of this cycle at CWMA were greater in treatments than in unmanaged stands, and greater in savannas than in woodlands. Gains in graminoid groundcover at CWMA appeared to stabilize after the third fire; increases in treatments from 2015 to 2016 did not yield levels greater than that observed prior to the third fire. Graminoid groundcover response to thinning, as observed before the effects of fire (2014), was generally comparable to CWMA at GRGL and LBL (10 to $15 \%$ increase). Post-thinning levels of graminoid groundcover at GRGL (2014) more than tripled following fire (to 2016), but fire did not substantially change graminoid groundcover at LBL over the same period (Fig. 2).

End-result (2016) graminoid groundcover was greater in thinned and burned treatments than unmanaged stands at all sites (Table 3, Fig. 3). Where three burns occurred (CWMA), thinned and burned stands had an additional 29\% of graminoid groundcover relative to unmanaged stands. This difference was less substantial (mean $=19 \%$ increase) at sites where only a single fire was applied (GRGL and LBL). Burning alone, regardless of season, did not significantly alter graminoid groundcover relative to unmanaged stands. We also did not observe fire-season effects on graminoid groundcover within final (2016) treatment observations (Fig. 3, Table 3). Effects of thinning level varied by site. At CWMA, final graminoid groundcover was $31 \%$ greater in savannas relative to woodlands, but woodlands did not differ from unmanaged stands (Fig. 3, Table 3). At GRGL, thin and burn treatments increased graminoid groundcover 


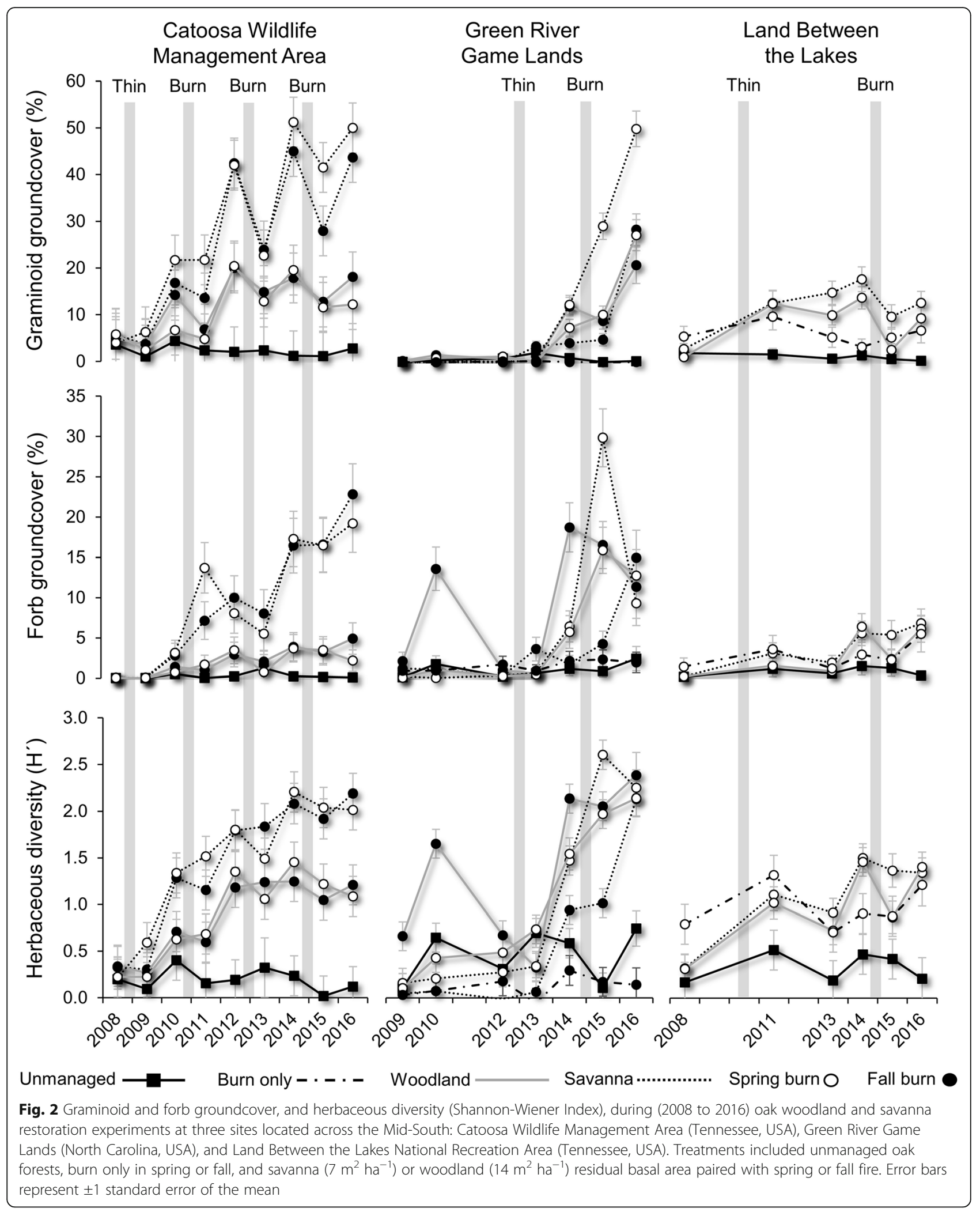

by an average of 5 -fold relative to unmanaged stands (Fig. 3). Graminoid groundcover in spring-burned savannas at GRGL was $17 \%$ greater than fall-burned woodlands, and spring-burned woodlands and fallburned savannas were intermediate between these treatments. Thinning and burning increased 
Table 2 Overall (2008 to 2016) and end-result (2016) ANCOVA and ANOVA model results for groundcover variables observed within oak woodland and savanna restoration experiments at CWMA (Catoosa Wildlife Management Area, Cumberland County, Tennessee, USA), GRGL (Green River Game Lands, Polk County, North Carolina, USA), and LBL (Land Between the Lakes National Recreation Area, Stewart County, Tennessee, USA). Richness and diversity (Shannon-Wiener Index) refer to the herbaceous community. Boldface values indicates significant $(a=0.05)$ and interpretable effects. Model df calculated using Kenward-Roger adjustment

\begin{tabular}{|c|c|c|c|c|c|c|c|c|c|}
\hline \multirow[b]{3}{*}{ Site } & \multirow{3}{*}{$\begin{array}{l}\text { Groundcover } \\
\text { variable }\end{array}$} & \multicolumn{6}{|c|}{ Overall model (2008 to 2016) } & \multirow{2}{*}{\multicolumn{2}{|c|}{$\frac{\text { End result (2016) }}{\text { Treatment }}$}} \\
\hline & & \multicolumn{2}{|c|}{ Treatment } & \multicolumn{2}{|l|}{ Year } & \multicolumn{2}{|c|}{ Treatment $\times$ Year } & & \\
\hline & & $\bar{F}$ & $P$ & $\bar{F}$ & $P$ & $\bar{F}$ & $P$ & $\bar{F}$ & $P$ \\
\hline \multirow[t]{8}{*}{ CWMA } & Graminoid & 5.1 & 0.051 & 59.2 & $<0.001$ & 9.7 & $<0.001$ & 5.9 & 0.040 \\
\hline & Forb & 6.7 & 0.029 & 62.0 & $<0.001$ & 7.7 & $<0.001$ & 9.6 & 0.015 \\
\hline & Richness & 6.3 & 0.034 & 70.1 & $<0.001$ & 9.5 & $<0.001$ & 8.8 & 0.017 \\
\hline & Diversity & 7.3 & 0.025 & 81.0 & $<0.001$ & 8.3 & $<0.001$ & 6.7 & 0.031 \\
\hline & Woody & 26.6 & 0.001 & 144.8 & $<0.001$ & 10.5 & $<0.001$ & 31.9 & 0.001 \\
\hline & Litter & 84.6 & $<0.001$ & 109.6 & $<0.001$ & 6.7 & $<0.001$ & 119.8 & $<0.001$ \\
\hline & Debris & 1.5 & 0.334 & 22.5 & $<0.001$ & 3.7 & $<0.001$ & 5.9 & 0.039 \\
\hline & Bare & 27.6 & $<0.001$ & 37.1 & $<0.001$ & 6.8 & $<0.001$ & 0.4 & 0.831 \\
\hline \multirow[t]{8}{*}{ GRGL } & Graminoid & 44.0 & $<0.001$ & 93.8 & $<0.001$ & 16.4 & $<0.001$ & 11.4 & $<0.001$ \\
\hline & Forb & 15.3 & $<0.001$ & 34.9 & $<0.001$ & 5.8 & $<0.001$ & 4.6 & 0.002 \\
\hline & Richness & 34.3 & $<0.001$ & 64.8 & $<0.001$ & 8.0 & $<0.001$ & 18.5 & $<0.001$ \\
\hline & Diversity & 48.7 & $<0.001$ & 71.1 & $<0.001$ & 9.6 & $<0.001$ & 23.3 & $<0.001$ \\
\hline & Woody & 21.4 & $<0.001$ & 9.0 & $<0.001$ & 8.6 & $<0.001$ & 19.6 & $<0.001$ \\
\hline & Litter & 29.7 & $<0.001$ & 36.7 & $<0.001$ & 10.3 & $<0.001$ & 43.6 & $<0.001$ \\
\hline & Debris & 7.1 & $<0.001$ & 12.4 & $<0.001$ & 3.7 & $<0.001$ & 1.4 & 0.243 \\
\hline & Bare & 16.9 & $<0.001$ & 53.4 & $<0.001$ & 9.7 & $<0.001$ & 10.9 & $<0.001$ \\
\hline \multirow[t]{8}{*}{ LBL } & Graminoid & 7.8 & 0.009 & 13.3 & $<0.001$ & 6.5 & $<0.001$ & 5.0 & 0.030 \\
\hline & Forb & 1.3 & 0.343 & 24.3 & $<0.001$ & 3.2 & $<0.001$ & 2.3 & 0.160 \\
\hline & Richness & 3.3 & 0.079 & 30.2 & $<0.001$ & 6.0 & $<0.001$ & 2.7 & 0.118 \\
\hline & Diversity & 3.8 & 0.059 & 30.6 & $<0.001$ & 5.6 & $<0.001$ & 4.3 & 0.044 \\
\hline & Woody & 6.9 & 0.012 & 66.7 & $<0.001$ & 6.4 & $<0.001$ & 4.4 & 0.041 \\
\hline & Litter & 25.7 & $<0.001$ & 55.8 & $<0.001$ & 8.1 & $<0.001$ & 14.5 & 0.001 \\
\hline & Debris & 7.4 & 0.012 & 12.9 & $<0.001$ & 1.9 & 0.017 & 4.6 & 0.037 \\
\hline & Bare & 3.6 & 0.065 & 34.8 & $<0.001$ & 3.3 & $<0.001$ & 0.9 & 0.474 \\
\hline
\end{tabular}

graminoid groundcover by $11 \%$ at LBL relative to unmanaged stands, and results were similar in woodlands and savannas. Graminoid groundcover often decreased with increasing slope and towards northeasterly aspects, and slope position effects varied by site. These relationships also changed over time, as indicated by differences in covariate significance and slope between overall (2008 to 2016) and end-result (2016) models (Additional file 3).

\section{Forb groundcover}

Pre treatment, we encountered 5, 67, and 29 species of forbs at CWMA, GRGL, and LBL, respectively. Only a fraction of these species were encountered more than five times prior to treatment at CWMA (1 species: Desmodium nudiflorum [L.] DC.) and LBL (3 species: Actaea racemosa L., Desmodium nudiflorum,
Pycnanthemum pycanthemoides [Leavenworth] Fernald). The relatively greater number of pre-treatment forb species detected at GRGL relative to other sites was, at least in part, related to the number of years across which pretreatment monitoring took place (three years at GRGL, one year at other sites). However, pre-treatment encounters at GRGL with each of these forb species only averaged $2.1 \mathrm{yr}^{-1}( \pm 0.6 \mathrm{SE})$. By 2016, we cumulatively documented 177 (CWMA), 140 (GRGL), and 141 (LBL) forb species and frequently encountered many of these species during monitoring efforts (Additional file 2). This included a 3-fold increase in average encounter rate per forb species at GRGL by 2016 (6.8 \pm 2.2 SE). Relative to average encounters in unmanaged stands, applied disturbances appeared to have a negative effect on $7 \%$ (19) of the 259 documented species of legumes and other forbs across all three sites (Additional file 2). American 
Table 3 Significant $(a=0.05)$ orthogonal treatment contrasts for groundcover variables at the conclusion (2016) of oak woodland and savanna restoration experiments at Catoosa Wildlife Management Area (CWMA, Tennessee, USA), Green River Game Lands (GRGL, North Carolina, USA), and Land Between the Lakes National Recreation Area (LBL, Tennessee, USA). Contrasts compared: unmanaged to thinned and burned stands (UN vs. TB); unmanaged to burned only stands (UN vs. BO); burned only to thinned and burned stands (BO vs. TB); woodland $\left(14 \mathrm{~m}^{2} \mathrm{ha}^{-1}\right)$ to savanna $\left(7 \mathrm{~m}^{2} \mathrm{ha}^{-1}\right)$ residual basal area (W vs. S); and fall (October) to spring (March) fire (Fa vs. Sp). BO treatments did not occur at CWMA, and Fa treatments did not occur at LBL. Richness and diversity (Shannon-Wiener Index) refer to the herbaceous community. Model df calculated using Kenward-Roger adjustment

\begin{tabular}{|c|c|c|c|c|c|c|}
\hline Site & Groundcover category & Contrast & $F$ & $P$ & Estimated cover (\%) & SE \\
\hline \multirow[t]{13}{*}{ CWMA } & \multirow[t]{2}{*}{ Graminoid } & UN vs. TB & 9.2 & 0.029 & +28.6 & 9.4 \\
\hline & & W vs. S & 13.9 & 0.014 & +31.4 & 8.4 \\
\hline & \multirow[t]{2}{*}{ Forb } & UN vs. TB & 17.1 & 0.009 & +14.1 & 4.7 \\
\hline & & W vs. S & 20.2 & 0.006 & +16.2 & 4.2 \\
\hline & \multirow[t]{2}{*}{ Richness } & UN vs. TB & 15.4 & 0.011 & +8.9 & 2.3 \\
\hline & & W vs. S & 19.2 & 0.007 & +8.9 & 2.0 \\
\hline & \multirow[t]{2}{*}{ Diversity } & UN vs. TB & 17.7 & 0.008 & +1.6 & 0.4 \\
\hline & & W vs. S & 8.8 & 0.032 & +1.0 & 0.3 \\
\hline & \multirow[t]{2}{*}{ Woody } & UN vs. TB & 118.6 & $<0.001$ & +48.2 & 4.4 \\
\hline & & W vs. S & 6.7 & 0.049 & +10.3 & 4.0 \\
\hline & \multirow[t]{2}{*}{ Litter } & UN vs. TB & 455.7 & $<0.001$ & -48.9 & 2.3 \\
\hline & & W vs. S & 24.8 & 0.004 & -10.2 & 2.0 \\
\hline & Debris & W vs. S & 18.8 & 0.008 & -5.7 & 1.3 \\
\hline \multirow[t]{17}{*}{ GRGL } & Graminoid & UN vs. TB & 23.0 & $<0.001$ & +24.7 & 5.2 \\
\hline & \multirow[t]{2}{*}{ Forb } & UN vs. TB & 11.4 & 0.001 & +10.8 & 3.6 \\
\hline & & BO vs. TB & 14.5 & $<0.001$ & +10.3 & 3.5 \\
\hline & \multirow[t]{2}{*}{ Richness } & UN vs. TB & 47.4 & $<0.001$ & +7.9 & 1.2 \\
\hline & & BO vs. TB & 71.9 & $<0.001$ & +9.2 & 1.1 \\
\hline & \multirow[t]{3}{*}{ Diversity } & UN vs. TB & 45.4 & $<0.001$ & +1.3 & 0.2 \\
\hline & & UN vs. BO & 5.3 & 0.026 & -0.5 & 0.2 \\
\hline & & BO vs. TB & 100.1 & $<0.001$ & +1.8 & 0.2 \\
\hline & \multirow[t]{3}{*}{ Woody } & UN vs. TB & 23.1 & $<0.001$ & +23.5 & 4.9 \\
\hline & & UN vs. BO & 12.8 & 0.001 & -21.3 & 5.9 \\
\hline & & BO vs. TB & 90.3 & $<0.001$ & +44.8 & 4.7 \\
\hline & \multirow[t]{2}{*}{ Litter } & UN vs. TB & 98.2 & $<0.001$ & -37.3 & 3.8 \\
\hline & & BO vs. TB & 159.6 & $<0.001$ & -45.9 & 3.6 \\
\hline & \multirow[t]{4}{*}{ Bare } & UN vs. TB & 10.6 & 0.002 & +5.5 & 2.1 \\
\hline & & UN vs. BO & 35.8 & $<0.001$ & +11.5 & 2.4 \\
\hline & & BO vs. TB & 15.7 & $<0.001$ & -6.0 & 1.9 \\
\hline & & Fa vs. Sp & 4.2 & 0.047 & +2.4 & 1.9 \\
\hline \multirow[t]{10}{*}{ LBL } & Graminoid & UN vs. TB & 14.4 & 0.005 & +12.8 & 4.4 \\
\hline & Forb & UN vs. TB & 6.7 & 0.033 & +8.2 & 4.1 \\
\hline & Richness & UN vs. TB & 8.0 & 0.022 & +4.7 & 1.7 \\
\hline & \multirow[t]{2}{*}{ Diversity } & UN vs. TB & 12.8 & 0.007 & +1.1 & 0.3 \\
\hline & & UN vs. BO & 5.8 & 0.043 & +1.0 & 0.4 \\
\hline & Woody & UN vs. TB & 11.0 & 0.011 & +28.0 & 8.4 \\
\hline & \multirow[t]{3}{*}{ Litter } & UN vs. TB & 39.6 & $<0.001$ & -47.5 & 7.6 \\
\hline & & UN vs. BO & 9.3 & 0.021 & -27.5 & 9.6 \\
\hline & & BO vs. TB & 7.0 & 0.029 & -20.0 & 7.6 \\
\hline & Debris & BO vs. TB & 11.4 & 0.010 & +3.6 & 1.4 \\
\hline
\end{tabular}


burnweed (Erechtites hieraciifolia [L.] Raf. ex DC.) was the most or second most commonly encountered forb at all sites. The genera Eupatorium L. (9 species), Solidago L. (15 species), and Viola L. (10 species) accounted for much of the forb diversity across our study. Herbaceous composition was similar at CWMA and GRGL, but more distinct at LBL; six of the top ten most frequently encountered forbs at LBL were legumes. Across all sites, the genera Lespedeza Michx.(7 species) and Desmodium Desv.(9 species) accounted for many of the commonly encountered legumes. One non-native, invasive forb, miniature beefsteakplant (Mosla dianthera [Buch.-Ham. ex Roxb.] Maxim.), was encountered twice at CWMA in disturbed treatments.

Forb groundcover increased more over time in thinned and burned treatments relative to unmanaged stands at all sites (Tables 2 and 3, Fig. 2). Increases in forb groundcover at CWMA were greater in savannas relative to other treatments, and most of this increase occurred from the first to second year post second fire (2013 to 2014). Forb groundcover response at GRGL was more erratic, perhaps because treatments were not replicated at the site, but did increase more in thin and burn treatments relative to unmanaged stands. Forb groundcover rarely exceeded $5 \%$ at LBL but increased in all treatments relative to unmanaged stands. End-result (2016) forb groundcover was greater in thin and burn treatments relative to unmanaged stands at all three sites by an average of $11 \%$ (Table 3). At CWMA, forb groundcover was $16 \%$ greater in savannas relative to woodlands, which did not differ from unmanaged stands. Burning alone, regardless of season, did not increase forb groundcover relative to unmanaged stands. Thinning and burning at GRGL and LBL increased forb groundcover by an average of 7 -fold relative to unmanaged stands. Forb groundcover in 2016 was comparable across differences in fire season, and we did not observe relationships between forb groundcover and tested topographical covariates (Additional file 3).

\section{Herbaceous richness and diversity}

We encountered 118 unique herbaceous species, inclusive of ferns, across all sites prior to treatments. By the conclusion of monitoring (2016), we had cumulatively documented 359 herbaceous species (Additional file 2). Similar site-specific figures indicated 13.6-fold (CWMA, 19 to 258 species), 2.1-fold (GRGL, 92 to 195 species), and 5.1-fold (LBL, 41 to 211 species) increases in total herbaceous species richness over our study's duration. Relative to average encounters in unmanaged stands, applied disturbances appeared to negatively affect $6 \%$ (23 of 359) of the documented herbaceous species across all three sites (Additional file 2).

Trends in herbaceous richness and diversity over time differed by treatment at all sites (Table 2, Fig. 2). Richness and diversity increased more rapidly, and ended up greater, in thinned and burned treatments relative to unmanaged stands at all sites (Tables 2 and 3, Fig. 3). Herbaceous diversity across thinned and burned treatments in 2016 was 20.6-fold, 3.4-fold, and 6.5-fold greater than unmanaged stands at CWMA, GRGL, and

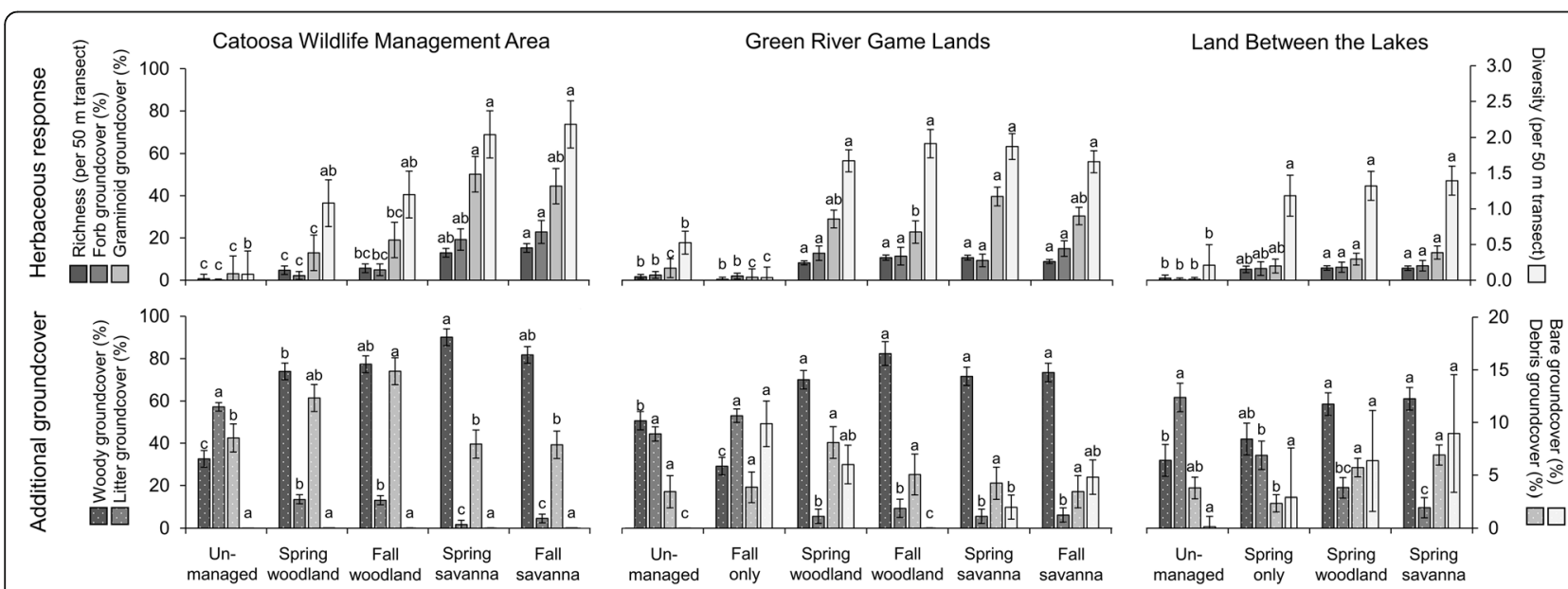

Fig. 3 Differences in herbaceous response (top row: species richness, forb and graminoid groundcover, and diversity as indicated by ShannonWiener Index) and additional groundcover measures (bottom row: woody, leaf litter, debris, and bare groundcover) in the final year of monitoring (2016) oak woodland and savanna restoration experiments at three sites located across the Mid-South: Catoosa Wildlife Management Area (Tennessee, USA), Green River Game Lands (North Carolina, USA), and Land Between the Lakes National Recreation Area (Tennessee, USA). Treatments included unmanaged oak forests, burn only in spring or fall, and savanna $\left(7 \mathrm{~m}^{2}\right.$ ha $\left.{ }^{-1}\right)$ or woodland $\left(14 \mathrm{~m}^{2}\right.$ ha $\left.{ }^{-1}\right)$ residual basal area paired with spring (March) or fall (October) fire. Lowercase letters represent significant $(a=0.05)$ differences by LSD mean separation following significant ANCOVA and ANOVA tests (Table 2). Please also consult Table 3 for significant orthogonal contrasts. Error bars represent \pm 1 standard error of the mean 
LBL, respectively. Repeated burning at CWMA also appeared to promote greater herbaceous richness and diversity in savannas relative to woodlands-a distinction absent from GRGL and LBL, where only a single fire occurred (Table 3, Figs. 2 and 3). Comparing unmanaged stands to fire-only treatments in 2016 (Fig. 3) indicated that burning alone: (1) had limited effects on herbaceous richness; (2) reduced diversity 14-fold when applied in the fall (GRGL); and (3) increased diversity 5-fold when applied in the spring (LBL). Herbaceous richness and diversity in 2016 never differed across fire season (Table 3, Fig. 3) and, at GRGL, decreased as aspects became more northeasterly. Additional relationships with slope, slope position, and aspect were observed within overall sitespecific models (2008 to 2016; Additional file 3). Thinning and repeated burning's positive effects on herbaceous groundcover, richness, and diversity were evident within pre- (2008) and post- (2016) treatment images at CWMA (Fig. 4).

\section{Additional groundcover measures}

Non-herbaceous groundcover trends over time (Table 2, Fig. 5), and end-result (2016) comparisons among treatments (Table 3), provided insights into potential mechanisms driving observed herbaceous response. Relative to unmanaged stands, thinning and fire promoted woody, debris, and bare groundcover, and reduced litter. Across all sites, woody groundcover was initially substantial (mean $34.8 \% \pm 3.4 \mathrm{SE}$ ), remained relatively constant or slightly increased in unmanaged stands, but more than doubled in thinned and burned stands across all sites by $2016(73.8 \% \pm 3.0 \mathrm{SE})$. Burn-only treatment in the fall at GRGL was the only treatment that reduced woody groundcover relative to unmanaged stands by $2016(-21 \%$; Table 3, Fig. 3). Additionally, and unlike other sites, final (2016) woody groundcover at CWMA was $10 \%$ greater in savannas relative to woodlands (Table 3). No effect of fire season on woody groundcover in 2016 was observed (Table 3, Fig. 3).

Litter groundcover decreased rapidly across all sites in thinned and burned stands relative to more constant or slight decreases in unmanaged stands (Fig. 5, Tables 2 and 3). In 2016, litter groundcover was $44.6 \%$ ( $\pm 4.6 \mathrm{SE}$ ) less, on average, in thinned and burned stands relative to unmanaged stands (Fig. 3, Table 3). Peaks in litter immediately after fire likely resulted from reductions in woody groundcover that caused more transect intervals to be classified as litter. Although final data (2016) analyses suggested that spring burning alone reduced litter groundcover relative to unmanaged stands at LBL (Fig. 3, Table 3), such differences existed prior to burning (Fig. 5). Also, fall burning alone did not reduce litter groundcover relative to unmanaged stands at GRGL. Litter groundcover in 2016 was $10 \%$ greater in woodlands than savannas at CWMA and did not differ across fire seasons at all sites (Table 3, Fig. 3).

Debris groundcover was relatively stable over time in unmanaged stands and burn-only treatments, but often increased after applied disturbances within thinned and burned stands (Table 2, Fig. 5). Within final (2016) observations (Table 3, Fig. 3), few differences in debris groundcover were observed; woodlands had $6 \%$ more than savannas at CWMA, and thinned and burned treatments had $4 \%$ more than burn-only treatments at LBL. Bare ground was consistently almost absent from unmanaged stands, but oscillated within all other treatments between greater levels in years immediately following disturbance (either thinning or burning) and reduced levels in the second year following disturbance (Table 2, Fig. 5). In 2016, bare ground was nearly absent from all treatments at CWMA and variable across treatments at other sites (Table 3, Fig. 3).
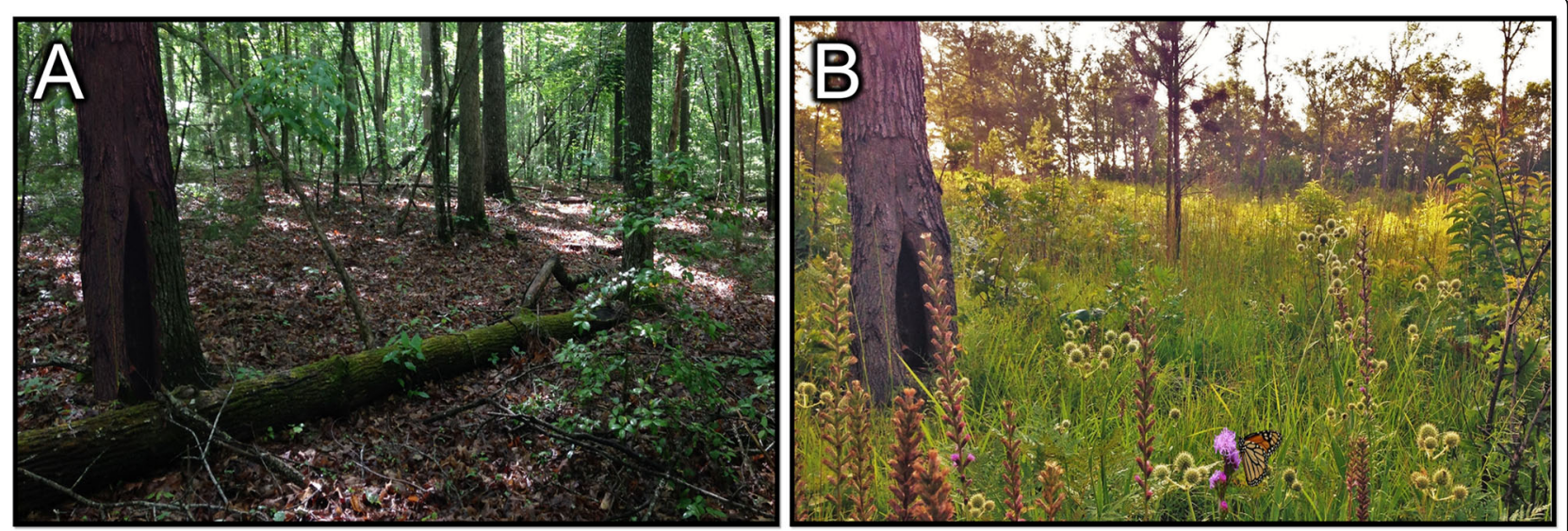

Fig. 4 Influence of oak woodland and savanna restoration on groundcover at Catoosa Wildlife Management Area near Crossville, Tennessee, USA. Panel A depicts pre-treatment conditions in 2008, and panel B depicts response by 2016 after thinning to $7 \mathrm{~m}^{2}$ ha ${ }^{-1}$ residual basal area and burning in October three years (2011, 2013, and 2015). Photographer was lead author A. Vander Yacht 


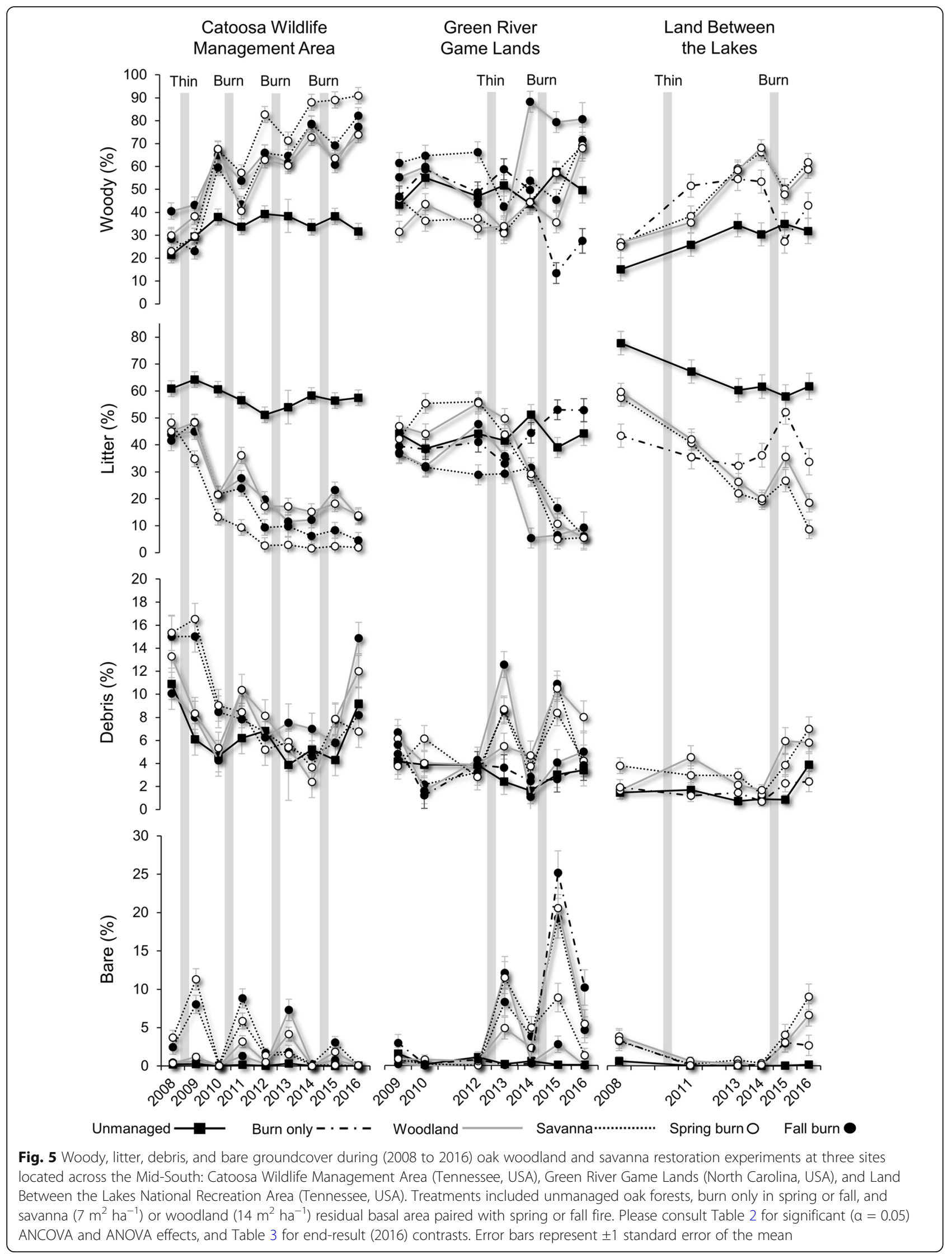




\section{Discussion}

Our results demonstrate just how drastically canopy disturbance and prescribed fire can alter groundcover in closed-canopy oak forests throughout the Mid-South. Before treatments, 118 herbaceous species constituted $<6 \%$ of groundcover. By 2016, 359 herbaceous species were recorded and herbaceous groundcover averaged $59 \%$ in repeatedly burned savannas. Only 6\% (23) of these species appeared negatively affected by treatments. Relative to unmanaged stands, thin-and-burn treatments increased graminoid (14-fold) and forb (50-fold) groundcover, and herbaceous richness (9-fold) and diversity (10-fold). These increases were often greater (11-, 123-, 14-, and 21- fold, respectively) where fire was repeatedly applied, and only after such management did herbaceous metrics in savannas exceed that of woodlands. Burn-only treatment and fire season differences rarely affected herbaceous metrics. Similar herbaceous ground-layer restoration in open-oak communities has been demonstrated outside of the Mid-South (Nielsen et al. 2003; Peterson and Reich 2008; Brudvig and Asbjornsen 2009; Lettow et al. 2014), but our results provide regionally specific evidence in support of such management. Using similar methods to promote herbaceous layers in Eastern oak ecosystems could address woodland and savanna decline (Nuzzo 1986; Noss et al. 1995), benefit associated wildlife (Harper et al. 2016; Vander Yacht et al. 2016), and improve ecological resiliency in the face of forecasted climatic change (Vose and Elliott 2016).

Such substantial herbaceous response from seemingly inconspicuous leaf-litter layers begs the question: Where did it all come from? Previous research and studyspecific context can provide some answers. Fire was historically frequent across study site regions (Lafon et al. 2017), and delineated stands captured the southwesterly aspects and ridges where open-oak communities likely occurred (DeSelm 1994). Our own model covariates indicated herbaceous metrics increased with such topography (Additional file 3). Free-range cattle grazing occurred at CWMA until 1947 (Coffey 2012), but sites otherwise lacked recent agricultural activity. As a result, on-site seedbanks likely included prairie flora (Keyser et al. 2012). Stands at CWMA were adjacent to $>1214$ hectares of oak savanna management. Other sites were imbedded in a matrix of closed-canopy forest, but early successional fields and prescribed fire often occurred nearby. Prairie flora (e.g., $\mathrm{C}_{4}$ grasses) were common along roads at all sites. Thus, wind and animal dispersal of seeds into stands likely occurred. We also observed $\mathrm{C}_{4}$ grasses $>2 \mathrm{~m}$ tall in the growing season after canopy disturbance, suggesting that dormant rhizomes were present. Where pre-treatment monitoring spanned more time, more herbaceous species were documented, suggesting that many species were already present in stands at relatively low abundance. Thus, the observed herbaceous response likely originated from multiple sources.

Exotic and invasive species response during our study was low. Only three such species were documented (Nepalese browntop, Chinese silvergrass, and miniature beefsteakplant), but all appeared to respond positively to treatments and never occurred in unmanaged stands (Additional file 2). Nepalese browntop occurred at all sites and was frequently encountered. The remaining invasive species were even less common, occurring at single sites (Chinese silvergrass at GRGL, miniature beefsteakplant at CWMA) and only in thinned and burned treatments. Disturbance often promotes invasive species that complicate restoration (Brewer et al. 2015), but selecting restoration sites where they are absent, or treating known populations prior to management, can prevent their proliferation.

\section{Light, overstory canopies, and understory sub-canopies}

In our study, all herbaceous metrics increased after canopy disturbance and before burning, and burn-only treatments rarely had positive effects on herbaceous layers. Additionally, greater herbaceous response occurred in savannas relative to woodlands after repeated burning. Overstory thinning can immediately create broken canopies that promote herbaceous-layer development by allowing light to reach ground layers (Nielsen et al. 2003; Peterson and Reich 2008; Brudvig and Asbjornsen 2009; Lettow et al. 2014; Brewer 2016). In contrast, burning alone can take $>60$ years to reduce canopy density (Burton et al. 2011; Knapp et al. 2015). Previous work at CWMA established that herbaceous cover, richness, and diversity were all negatively related to basal area and canopy closure (Barrioz et al. 2013; Vander Yacht et al. 2017a). Beyond effects on light, mechanical thinning creates understory heterogeneity in a variety of plant resources (e.g., soil moisture, nutrients), especially when conducted irregularly, and these gradients support increases in herbaceous diversity (Nielsen et al. 2003; Brudvig and Asbjornsen 2009) like those we observed.

We observed evidence suggesting that forbs at some sites were less resilient to decades of canopy closure relative to graminoids. Forb response was often only a fraction of that observed for graminoids, and substantial increases in forb groundcover either: (1) required savanna overstory conditions and repeated fire (CWMA); or (2) occurred at our most mesic site (GRGL), where forb composition included many shade-tolerant species (Additional file 2). In contrast, graminoid composition across all sites included many shade-tolerant, coolseason species (e.g., needlegrass, Carex spp., and Dichanthelium spp.). Increasing forb groundcover in upland oak forests often occurs slowly over multiple fires 
(Hutchinson et al. 2005), and we suggest that this is because such sites lack propagules of the shade-tolerant forb species that can quickly respond to applied disturbances. Upland oak sites were historically dominated by shade-intolerant forbs, but decades of closed-canopy conditions have depleted the seedbank of such species through outright elimination and negative effects on flowering rates (Nielsen et al. 2003). Leaf-litter dominance in closed-canopy environments also promotes acidic soils that limit forb establishment and growth (Ferguson et al. 2013). Thus, it may generally hold that a commitment to long-term management will be required to substantially increase forb groundcover on xeric, upland sites.

Increases in herbaceous response across the transition from woodland to savanna only occurred where fire was repeatedly applied (CWMA). The basal area target for savannas at LBL was greater $\left(9 \mathrm{~m}^{2} \mathrm{ha}^{-1}\right)$ relative to other sites $\left(7 \mathrm{~m}^{2} \mathrm{ha}^{-1}\right)$, and all thinning at LBL was restricted by USFS policy to narrow, flat ridges within stands. Resulting minimal variation in overstory conditions across treatments at LBL (Fig. 1) did not elicit a difference in herbaceous response. At GRGL, and in early restoration stages at CWMA, treatment overstory conditions were much more distinct (Fig. 1), but many dominant herbaceous species were light-seeded, ruderal forbs (e.g., American burnweed), and shade-tolerant, cool-season grasses (e.g., needlegrass; Additional file 2). This early herbaceous composition, perhaps typical after decades of canopy closure (Vander Yacht et al. 2017a), may have reduced canopy cover influence until more shade-intolerant species (e.g., $\mathrm{C}_{4}$ grasses) were stimulated by repeated fire.

Canopy disturbance also promoted woody competition in the understory. Dense sub-canopies of woody shrubs, seedlings, and saplings often negatively affect herbaceous-layer development (Briggs et al. 2005; Peterson et al. 2007; Barrioz et al. 2013), yet across our study, herbaceous metrics were often greatest where woody groundcover was the greatest. We believe that this again reflects the relative shade tolerance of many herbaceous species responding during the early stages of restoration. Dense, woody understories may become more problematic as herbaceous composition transitions towards more conservative and shade-intolerant species (Brewer and Menzel 2009; Brewer 2016). Herbicide or mechanical treatments that reduce understory woody competition may be required to further advance herbaceous response (Lettow et al. 2014; Vander Yacht et al. 2017b). Regardless, fire effects on herbaceous communities are minimal without canopy disturbance (Hutchinson et al. 2005), and our results clearly show increases in herbaceous metrics with increasing canopy disturbance and repeated fire.

\section{Fire effects on herbaceous layers in Eastern oak communities}

Our results provide insights into the mechanisms behind the positive effects of fire on the herbaceous components of Eastern deciduous forests. Fire promotes herbaceous development by reducing understory woody competition (Knapp et al. 2015), consuming germination-inhibiting layers of leaf litter and debris (Lashley et al. 2011), increasing soil nutrient availability (Scharenbroch et al. 2012), and improving seed germination rates (Emery et al. 2011). In our study, fire reduced litter groundcover by $48 \%$ and biennially increased bare ground. These effects were likely more important in directing herbaceous response than woody competition control because woody groundcover increased over time in all thinned and burned treatments. Glasgow and Matlack (2007) suggested that fire's reduction of litter and effects on soil nutrients were more important than canopy openness in directing herbaceous response, but admitted that the small size of canopy gaps within their study may have failed to alter understory microclimates. We believe that fire's effects in our study on leaf litter and debris, and likely soil nutrients and seed germination rates, were additive to the positive effects of adequate canopy disturbance on herbaceous response. Suppressing woody competition can require decades of frequent (every one to two years) burning (Hutchinson et al. 2012; Arthur et al. 2015), and associated herbaceous benefits of such competition reduction may be restricted to the later stages of restoration. Further, the more immediate mechanisms of fire's herbaceous promotion, such as litter reduction, may be disproportionately important based on positive feedbacks between herbaceous finefuel loads and fire's ability to control woody vegetation (Peterson and Reich 2001; Nielsen et al. 2003).

The positive effects of fire on herbaceous cover, richness, and diversity that we observed appear to directly conflict with assertions that fire reduces diversity east of the prairie-woodland transition zone (Matlack 2013, 2015). Such assertions suggest that fire may have negative effects in more mesic and fire-intolerant forest communities, but our results and others (Stambaugh et al. 2015) demonstrate consistently positive effects of fire on the herbaceous layers of upland oak forests throughout the Mid-South. This included our demonstration of positive effects at GRGL, a relatively more mesic site. In addition, Brewer et al. (2015) observed increases in herbaceous species following fire that were indicative of both open woodlands and forests, and no declines in any mesic forest indicators. Annual to biennial fire has been shown to maximize understory species richness within oak ecosystems (Peterson and Reich 2008; Burton et al. 2011). In our study, such a fire regime appeared to negatively affect only $6 \%$ of the 359 encountered herbaceous species. 
Some herbaceous species were more common in specific fire-season treatments (Additional file 2), but no effect of fire season on more broad herbaceous metrics was observed. Few studies have evaluated the effects of seasonal variation in fire on herbaceous understories of Eastern hardwood ecosystems (Knapp et al. 2009). Consistently applying fires near seasonal peaks in seed production, or growth of specific species, would likely alter composition. We found it difficult to isolate fire-season effects on herbaceous layers from fire intensity effects. Spring fires were consistently more intense than fall fires, as suggested by 2 -fold differences in flame lengths and rates of spread, and $40{ }^{\circ} \mathrm{C}$ hotter pyrometer tile surfaces (Additional file 1). Increased wind speed in the spring relative to fall appeared to cause these differences. Fine fuels were drier in the fall, when it was also hotter, and 10-hour fuel moisture, wind direction, and relative humidity did not differ between fire seasons. Fine-fuel loads (1-hour and leaf litter) also rarely differed across fire-season treatments, and when they did, were lower in spring treatments (Vander Yacht et al. 2019). Herbaceous development can increase with increasing fire intensity (McMurry et al. 2007), but response after less intense fall fires was comparable to that following more intense spring fires. This does suggest utility for fall fires related to ease of control while promoting comparable herbaceous response to more intense spring burns.

We suggest that plausible explanations exist for the similarities in herbaceous response across fires that differed in intensity by season. Fire likely precluded even greater increases in understory woody competition by inducing stem mortality, which increases with increasing fire temperature and duration of exposure (Michaletz and Johnson 2007). Perhaps the slower spread of October fires and related increase in heat exposure duration compensated for lower fire intensity relative to March burning. The timing of fire in relation to plant phenology, such as seasonally reduced root carbohydrate reserves (Loescher et al. 1990), may have also compensated for observed differences in intensity. It is also possible that October is too late at our latitude and altitude to gain a benefit in woody plant control related to phenology (Huddle and Pallardy 1999). In that case, earlier growing-season fire (August or September) may relatively accelerate herbaceous-layer restoration. Effects of seasonal variation in fire on herbaceous communities often only become apparent after long-term, repeated burning (Knapp et al. 2009), so continued monitoring could reveal an effect. Research that better isolates the effects of fire season from seasonal differences in intensity is needed for a more complete understanding of herbaceous-layer response. Regardless, transitioning understory dominance from woody to herbaceous plants in Eastern oak communities may require more than repeated, dormant-season fire (Hutchinson et al. 2012), and non-fire alternatives are often more labor and cost intensive (e.g., herbicides; Vander Yacht et al. 2017b).

\section{Conclusions}

Herbaceous-layer response was maximized in repeatedly burned savannas. Relative to unmanaged stands, such treatments increased graminoid groundcover 11-fold, forb groundcover 123-fold, herbaceous richness 14-fold, and herbaceous diversity 21 -fold, but no differences were observed between fall and spring fire (H1, H5). Burnonly treatments rarely had positive effects on herbaceous response, highlighting the importance of canopy disturbance $(\mathrm{H} 2)$. Thin and burn treatments increased all herbaceous metrics at all sites relative to unmanaged stands (H3). Herbaceous response in savannas was only greater than woodlands where fire was repeatedly applied (H4). Treatments appeared to negatively affect only $6 \%$ (23) of the 359 documented herbaceous species. Underlying mechanisms behind positive herbaceous responses appeared to involve reductions in germinations inhibiting layers of leaf litter and coarse woody debris, and biennial increases in bare ground. Even greater herbaceous response could be attained through understory woody competition control.

Our results can be used to direct the restoration of herbaceous ground layers in Eastern oak ecosystems. Restoration should begin by selecting a site where landuse history, seedbank potential, landscape context, and present herbaceous species are conducive to success. Burn-only was the only treatment to reduce understory woody competition, so burning prior to planned canopy disturbance may enhance results. Stands should be thinned to 7 or $14 \mathrm{~m}^{2} \mathrm{ha}^{-1}$ to mimic historical oak savanna or woodland structure, respectively. Prescribed fire should then be repeatedly applied. The recovery of understory woody groundcover within two growing seasons suggests the use of no less frequent than biennial fire. Where woody plant control with fire proves difficult, herbicides or mechanical removal treatments can be used. Similar herbaceous response after less intense October fires relative to more intense March fires suggests that an expanded burn window can be used (fall or spring). However, lower intensity fire may be preferred in some cases and fire in August or September may increase woody control and herbaceous response.

Positive herbaceous-layer response to thinning and prescribed fire after decades of fire exclusion demonstrates the resiliency of such community components and offers hope to the restoration of imperiled oak woodlands and savannas throughout the Mid-South. Current conservation programs across federal and state governmental agencies, and non-governmental organizations, often prioritize existing sites of determined high botanical quality. Our results suggest that such policies may overlook 
the tremendous restoration potential present in otherwise inconspicuous understories of closed-canopy oak forests throughout eastern North America.

\section{Supplementary information}

Supplementary information accompanies this paper at https://doi.org/10. 1186/s42408-020-00072-2.

Additional file 1. Seasonal comparison of weather, fuel moisture, and fire behavior for prescribed fires during (2008 to 2016) oak woodland and savanna restoration experiments at Catoosa Wildlife Management Area (CWMA; Cumberland County, Tennessee, USA), Green River Game Lands (GRGL; Polk County, North Carolina, USA), and Land Between the Lakes National Recreation Area (LBL; Stewart County, Tennessee, USA). Statistics based on a two-sample $t$-test assuming unequal variance ( $t$ : two-tailed test statistic, df: degrees of freedom, and $P$ : probability value).

Additional file 2. Encounters by site and treatment and general response to treatments (TRT) for herbaceous species during (2008 to 2016) oak restoration experiments at Catoosa Wildlife Management Area (CWMA; Cumberland County, Tennessee, USA), Green River Game Lands (GRGL; Polk County, North Carolina, USA), and Land Between the Lakes National Recreation Area (LBL; Stewart County, Tennessee, USA).

Treatments included unmanaged (UN), burn-only (O) in spring (Sp) or fall (Fa), and savanna $\left(7 \mathrm{~m}^{2} \mathrm{ha}^{-1}, \mathrm{~S}\right)$ or woodland $\left(14 \mathrm{~m}^{2} \mathrm{ha}^{-1}, \mathrm{~W}\right)$ residual basal area paired with spring (mid March) or fall (mid October) fire. We compared average encounters in treatments with average encounters in $\mathrm{UN}$, and labeled response as positive (,$+ \mathrm{UN}<$ treatments), negative $(-, \mathrm{UN}>$ treatments), neutral $(\mathrm{N}, \mathrm{UN}=$ treatments $)$, or rare $(\mathrm{R},<2$ total encounters).

Additional file 3. Significant ( $a=0.05$ ) covariates within overall (2008 to 2016) and end-result (2016) ANCOVA and ANOVA models of groundcover during monitoring of oak woodland and savanna restoration experiments at Catoosa Wildlife Management Area (Cumberland County, Tennessee, USA), Green River Game Lands (Polk County, North Carolina, USA), and Land Between the Lakes National Recreation Area (Stewart County, Tennessee, USA). Referenced statistics include the test statistic $(F)$ and probability value $(P)$.

\section{Acknowledgements}

We thank TWRA (at CWMA), North Carolina Wildlife Resources Commission (NCWRC at GRGL), and the US Forest Service (at LBL) for implementing treatments and providing field-season housing. We specifically thank TWRA staff M. Lipner, K. Kilmer, and C. Coffey (retired); US Forest Service Staff D. Wilson and R. Lomax; and NCWRC staff D. Simon. We also acknowledge numerous field technicians for assistance with data collection: P. Acker, C. Ault, L. Brinkman, J. Clark, E. Clarkson, M. Cox, M. Critean, K. Dreyer, T. Duke, C. Gresham, K. Goostree, R. Hunter, A. Jackson, A. Lambert, J. Lippert, K. McCoy, J. Myers, F. Nebenburgh, J. Orange, J. Redden, S. Snow, D. Stamey, C. Swafford, J. Tapp, J. Trussa, W. Underwood., S. White, and B. Whitley.

\section{Authors' contributions}

PDK, CK, MCS, and ALV designed the study design and wrote funding grants. SAB designed data collection protocols and collected 2008 to 2009 data. ALV adjusted these protocols, collected data from 2010 to 2016, ran analyses, and wrote initial manuscript drafts and revisions. PDK, CK, MCS, WKC, and RJ provided extensive feedback during analyses and manuscript editing. All authors read and approved the final manuscript.

\section{Funding}

We thank the Joint Fire Science Program (Project ID: 13-1-04-14), University of Tennessee (Department of Forestry, Wildlife, and Fisheries), Tennessee Wildlife Resources Agency (TWRA), and G.L. Lindemann Jr. for financial support of this research.

\section{Availability of data and materials}

The datasets used and analyzed during this study are available from the corresponding author on reasonable request.
Ethics approval and consent to participate

Not applicable.

\section{Consent for publication}

Not applicable.

\section{Competing interests}

The authors declare that they have no competing interests.

\section{Author details}

${ }^{1}$ Department of Forestry, Michigan State University, Natural Resources Building, 480 Wilson Road, Room 126, East Lansing, Michigan 48824-6402, USA. ${ }^{2}$ Department of Forestry, Wildlife, and Fisheries, University of Tennessee, Center for Native Grasslands Management, 274 Ellington Plant Sciences Building, Knoxville, Tennessee 37996, USA. ${ }^{3}$ Department of Forestry, Wildlife, and Fisheries, University of Tennessee, 274 Ellington Plant Sciences Building, Knoxville, Tennessee 37996, USA. ${ }^{4}$ Department of Forestry, University of Missouri, 203 Anheuser-Busch Natural Resources Building, Columbia, Missouri 65211, USA. ${ }^{5}$ North Carolina Wildlife Resources Commission, 8676 Will Hudson Road, Lawndale, North Carolina 28090, USA.

Received: 30 November 2019 Accepted: 22 April 2020

Published online: 06 July 2020

\section{References}

Abrams, M.D. 1992. Fire and the development of oak forests. BioScience 42: 346353 https://doi.org/10.2307/1311781.

Alexander, H.D., and M.A. Arthur. 2014. Increasing red maple leaf litter alters decomposition rates and nitrogen cycling in historically oak-dominated forests of the Eastern U.S. Ecosystems 17: 1371-1383 https://doi.org/10.1007/ s10021-014-9802-4

Arthur, M.A., B.A. Blankenship, A. Schorgendorfer, D.L. Loftis, and H.D. Alexander. 2015. Changes in stand structure and tree vigor with repeated prescribed fire in an Appalachian hardwood forest. Forest Ecology and Management 340: 4661 https://doi.org/10.1016/j.foreco.2014.12.025.

Babl, E., H.D. Alexander, C.M. Siegert, and J.L. Willis. 2020. Could canopy, bark, and leaf litter traits of encroaching non-oak species influence future flammability of upland oak forests? Forest Ecology and Management 458: 117731 https:// doi.org/10.1016/j.foreco.2019.117731.

Barrioz, S.A., P.D. Keyser, D.S. Buckley, D.A. Buehler, and C.A. Harper. 2013. Vegetation and avian response to oak savanna restoration in the Mid-South USA. American Midland Naturalist 169: 194-213 https://doi.org/10.1674/00030031-169.1.194

Beers, T.W., P.E. Dress, and L.C. Wensel. 1966. Notes and observations: aspect transformation in site productivity research. Journal of Forestry 64: 691-692.

Blankenship, B.A., and M.A. Arthur. 2006. Stand structure over 9 years in burned and fire-excluded oak stands on the Cumberland Plateau, Kentucky. Forest Ecology and Management 225: 134-145 https://doi.org/10.1016/.foreco.2005.12.032.

Bonham, C.D. 1989. Measurements for terrestrial vegetation. New York: Wiley.

Breshears, D.D. 2006. The grassland-forest continuum: trends in ecosystem properties for woody plant mosaics? Frontiers in Ecology and the Environment 4: 96-104 https://doi.org/10.1890/1540-9295(2006)004[0096:TGCTIE]2.0.CO;2.

Brewer, J.S. 2001. Current and presettlement tree species composition of some upland forests in northern Mississippi. Journal of the Torrey Botanical Society 128: 332-349 https://doi.org/10.2307/3088666.

Brewer, J.S. 2016. Natural canopy damage and the ecological restoration of fireindicative groundcover vegetation in an oak-pine forest. Fire Ecology 12: $105-$ 126 https://doi.org/10.4996/fireecology.1202105

Brewer, J.S., M.J. Abbott, and S.A. Moyer. 2015. Effects of oak-hickory woodland restoration treatments on native groundcover vegetation and the invasive grass, Microstegium vimineum. Ecological Restoration 33: 256-265 https://doi. org/10.3368/er.33.3.256

Brewer, J.S., and T. Menzel. 2009. A method for evaluating outcomes of restoration when no reference sites exist. Restoration Ecology 17: 4-11 https://doi.org/10.1111/j.1526-100X.2008.00456.x .

Briggs, J.M., A.K. Knapp, J.M. Blair, J.L. Heisler, G.A. Hoch, M.S. Lett, and J.K. McCarron. 2005. An ecosystem in transition: causes and consequences of the conversion of mesic grassland to shrubland. Bioscience 55: 243-254 https:// doi.org/10.1641/0006-3568(2005)055[0243:AEITCA]2.0.CO;2. 
Brudvig, L.A., and H. Asbjornsen. 2009. The removal of woody encroachment restores biophysical gradients in Midwestern oak savannas. Journal of Applied Ecology 46: 231-240 https://doi.org/10.1111/j.1365-2664.2008.01590.x.

Burton, J.A., S.W. Hallgren, S.D. Fuhlendorf, and D.M. Leslie. 2011. Understory response to varying fire frequencies after 20 years of prescribed burning in an upland oak forest. Plant Ecology 212: 1513-1525 https://doi.org/10.1007/ s11258-011-9926-y.

Clark, S.H.B. 2008. Geology of the Southern Appalachian Mountains: Scientific Investigations Map 2830, U.S. Geological Survey, Denver, CO, Available at https://pubs.usgs.gov/sim/2830/

Coffey, C. 2012. The history of shortleaf pine on the Cumberland Plateau. In: Proceedings of the shortleaf pine conference: east meets west - bridging the gap with research and education across the range, ed. J. Kush, R.J. Barlow, and J.C. Gilbert, 2-6. Huntsville: U.S. Department of Agriculture, Alabama Agricultural Experiment Station.

Cox, M.R., E.V. Willcox, P.D. Keyser, and A.L. Vander Yacht. 2016. Bat response to prescribed fire and overstory thinning in hardwood forest on the Cumberland Plateau, Tennessee. Forest Ecology and Management 359: $221-$ 231 https://doi.org/10.1016/j.foreco.2015.09.048.

Delcourt, P.A., H.R. Delcourt, C.R. Ison, W.E. Sharp, and K.J. Gremillion. 1998. Prehistoric human use of fire, the eastern agricultural complex, and Appalachian oak-chestnut forests: paleoecology of Cliff Palace Pond, Kentucky. American Antiquity 63: 263-278 https://doi.org/10.2307/2694697.

DeSelm, H.R. 1994. Tennessee barrens. Castanea 59: 214-225.

Emery, S.M., J. Uwimbabazi, and S.L. Flory. 2011. Fire intensity effects on seed germination of native and invasive Eastern deciduous forest understory plants. Forest Ecology and Management 261: 1401-1408 https://doi.org/10. 1016/j.foreco.2011.01.024

Faber-Langendoen, D., ed. 2001. Plant communities of the Midwest: classification in an ecological context. Arlington: Association for Biodiversity Information.

Ferguson, B.J., M.-H. Lin, and P.M. Gresshoff. 2013. Regulation of legume nodulation by acidic growth conditions. Plant signaling \& behavior 8: 1-5 https://doi.org/10.4161/psb.23426.

Fralish, J.S., S.B. Franklin, and D.D. Close. 2000. Open woodland communities of southern Illinois, western Kentucky, and middle Tennessee. In The Savanna, Barren, and Rock Outcrop Communities of North America, ed. R.C. Anderson, J.S. Fralish, and J. Baskin, 171-189. New York, New York: Cambridge University Press https://doi.org/10.1017/CBO9780511574627.011.

Franklin, S.B., P.A. Robertson, and J.S. Fralish. 2003. Prescribed burning effects on upland Quercus forest structure and function. Forest Ecology and Management 184: 315-335 https://doi.org/10.1016/S0378-1127(03)00153-1.

Gilliam, F.S., and M.R. Roberts. 2003. The dynamic nature of the herbaceous layer: synthesis and future directions for research. In The herbaceous layer in forests of eastern North America, ed. F.S. Gilliam and M.R. Roberts, 323-337. New York, NY: Oxford University Press.

Glasgow, L.S., and G.R. Matlack. 2007. Prescribed burning and understory composition in a temperate deciduous forest, Ohio, USA. Forest Ecology and Management 238: 54-64 https://doi.org/10.1016/j.foreco.2006.08.344.

Gruchy, J.P., C.A. Harper, and M.J. Gray. 2009. Methods for controlling woody invasion into CRP fields in Tennessee. In Gamebird 2006: Quail VI and Perdix XII, ed. S.B. Cederbaum, B.C. Faircloth, T.M. Terhune, J.J. Thompson, and J.P. Carroll, 315-321. Athens: Warnell School of Forestry and Natural Resources.

Guyette, R.P., D.C. Dey, M.C. Stambaugh, and R.M. Muzika. 2006. Fire scars reveal variability and dynamics of eastern fire regimes. In Fire in Eastern Oak Forests: Delivering Science to Land Managers: Proceedings of a Conference, ed. M.B. Dickinson, 20-39. Columbus: US Department of Agriculture, Forest Service, Fawcett Center, the Ohio State University.

Hanula, J.L., S. Horn, and J.J. O'Brien. 2015. Have changing forests conditions contributed to pollinator decline in the southeastern United States? Forest Ecology and Management 348: 142-152 https://doi.org/10.1016/j.foreco.2015.03.044.

Harper, C.A., M.W. Ford, M.A. Lashley, C.E. Moorman, and M.C. Stambaugh. 2016. Fire effects on wildlife in the Central Hardwoods and Appalachian Regions, USA. Fire Ecology 12: 127-159 https://doi.org/10.4996/fireecology.1202127.

Heikens, A.L., and P.A. Robertson. 1994. Barrens of the Midwest: A review of the literature. Castanea 59: 184-194.

Huddle, J.A., and S.G. Pallardy. 1999. Effect of fire on survival and growth of Acer rubrum and Quercus seedlings. Forest Ecology and Management 118: 49-56 https://doi.org/10.1016/S0378-1127(98)00485-X

Hutchinson, T.F., R.E.J. Boerner, S. Sutherland, E.K. Sutherland, M. Ortt, and I. L.R. 2005. Prescribed fire effects on the herbaceous layer of mixed-oak forests.
Canadian Journal of Forestry Research 35: 877-890 https://doi.org/10.1139/ x04-189.

Hutchinson, T.F., D.A. Yaussy, R.P. Long, J. Rebbeck, and E.K. Sutherland. 2012. Long-term (13-year) effects of repeated prescribed fires on stand structure and tree regeneration in mixed-oak forests. Forest Ecology and Management 286: 87-100 https://doi.org/10.1016/j.foreco.2012.08.036.

Jackson, S.W., C.A. Harper, D.S. Buckley, and B.F. Miller. 2006. Short-term effects of silvicultural treatments on microsite heterogeneity and plant diversity in mature Tennessee oak-hickory forests. Northern Journal of Applied Forestry 23: 197-203 https://doi.org/10.1093/njaf/23.3.197.

Keenan, S.C. 1998. Soil survey of Polk County, North Carolina. U.S. Dept. of Agriculture, Natural Resources Conservation Service, Washington, DC.

Kenward, M.G., and J.H. Roger. 1997. Small sample inference for fixed effects from restricted maximum likelihood. Biometrics 53: 983-997 https://doi.org/10. 2307/2533558

Keyser, T.L., T. Roof, J.L. Adams, D. Simon, and G. Warburton. 2012. Effects of prescribed fire on the buried seed bank in mixed-hardwood forests of the Southern Appalachian Mountains. Southeastern Naturalist 11: 669-688 https://doi.org/10.1656/058.011.0407.

Knapp, B.O., K. Stephan, and J.A. Hubbart. 2015. Structure and composition of an oak-hickory forest after over 60 years of repeated prescribed burning in Missouri, USA. Forest Ecology and Management 344: 95-109 https://doi.org/ 10.1016/j.foreco.2015.02.009.

Knapp, E. E., B. L. Estes, and C. N. Skinner. 2009. Ecological effects of prescribed fire season: a literature review and synthesis for managers. 1-80. U.S. Department of Agriculture Forest Service, Pacific Southwest Research Station, Albany. https://doi.org/10.2737/PSW-GTR-224

Knops, J.M.H., D. Tilman, N.M. Haddad, S. Naeem, C.E. Mitchell, J. Haarstad, M.E. Ritchie, K.M. Howe, P.B. Reich, E. Siemann, and J. Groth. 1999. Effects of plant species richness on invasion dynamics, disease outbreaks, insect abundances and diversity. Ecology Letters 2: 286-293 https://doi.org/10.1046/j.1461-0248. 1999.00083.x

Kreye, J.K., J.M. Varner, J.K. Hiers, and J. Mola. 2013. Toward a mechanism for eastern North American forest mesophication: differential litter drying across 17 species. Ecological Applications 23: 1976-1986 https://doi.org/10.1890/130503.1 .

Lafon, C.W., A.T. Naito, H.D. Grissino-Mayer, S.P. Horn, and T.A. Waldrop. 2017. Fire history of the Appalachian region: a review and synthesis, 97. Asheville: U.S. Department of Agriculture, Forest Service, Southern Research Station.

Lashley, M.A., C.A. Harper, G.E. Bates, and P.D. Keyser. 2011. Forage availability for white-tailed deer following silvicultural treatments in hardwood forests. Journal of Wildlife Management 75: 1467-1476 https://doi.org/10.1002/jwmg. 176

Leach, M.K., and T.J. Givnish. 1999. Gradients in the composition, structure, and diversity of remnant oak savannas in southern Wisconsin. Ecological Monographs 69: 353-374 https://doi.org/10.1890/0012-9615(1999)069[0353: GITCSA]2.0.CO;2.

Lettow, M.C., L.A. Brudvig, C.A. Bahlai, and D.A. Landis. 2014. Oak savanna management strategies and their differential effects on vegetative structure, understory light, and flowering forbs. Forest Ecology and Management 329: 89-98 https://doi.org/10.1016/j.foreco.2014.06.019.

Littell, R.C., G.A. Milliken, W.W. Stroup, R.D. Wolfinger, and O. Schabenberger. 2006. SAS for mixed models. 2nd ed. Cary: SAS Institute Inc.

Loescher, W.H., T. McCamant, and J.D. Keller. 1990. Carbohydrate reserves, translocation, and storage in woody plant-roots. Hortscience 25: 274-281 https://doi.org/10.21273/HORTSCI.25.3.274.

Magurran, A.E. 1988. Ecological diversity and its measurement. Princeton, New Jersey: Princeton University Press.

Matlack, G.R. 2013. Reassessment of the use of fire as a management tool in deciduous forests of Eastern North America. Conservation Biology 27: 916-926 https://doi.org/10.1111/cobi.12121.

Matlack, G.R. 2015. Managing fire in the mesic deciduous forest when fire history is unknown: response to Stambaugh et al. Conservation Biology 29: 947-949 https://doi.org/10.1111/cobi.12472.

Maynard, E.E., and J.S. Brewer. 2013. Restoring perennial warm-season grasses as a means of reversing mesophication of oak woodlands in Northern Mississippi. Restoration Ecology 21: 242-249 https://doi.org/10.1111/j.1526100X.2012.00871.x

McCord, J.M., C.A. Harper, and C.H. Greenberg. 2014. Brood cover and food resources for wild turkeys following silvicultural treatments in mature upland hardwoods. Wildlife Society Bulletin 38: 265-272 https:/doi.org/10.1002/wsb.403. 
McMurry, E.R., R.M. Muzika, E.F. Loewenstein, K.W. Grabner, and G.W. Hartman. 2007. Initial effects of prescribed burning and thinning on plant communities in the Southeast Missouri ozarks. e-Gen. Tech. Rep. SRS-101. U.S. Department of Agriculture, Forest Service, Southern Research Station: Asheville, NC. pp. 241-249

McPherson, G.R. 1997. Ecology and management of North American savannas. Tucson: University of Arizona Press.

Michaletz, S.T., and E.A. Johnson. 2007. How forest fires kill trees: a review of the fundamental biophysical processes. Scandinavian Journal of Forest Research 22: 500-515 https://doi.org/10.1080/02827580701803544.

Michaux, F.A. 1805. Travels to the westward of the Allegheny mountains, in the states of Ohio, Kentucky, and Tennessee, in the year 1802. London: Richard Phillips.

Mitchell, R.J., J.K. Hiers, J. O'Brien, and G. Starr. 2009. Ecological forestry in the Southeast: Understanding the ecology of fuels. Journal of Forestry 107: 391-397.

National Climatic Data Center. 2014. 1981-2010 Climate Normals: Crossville Memorial Airport, TN, U.S. http://www.ncdc.noaa.gov/land-based-stationdata/climatenormals/1981-2010-normals-data. Accessed 2 Feb 2014.

Nelson, P.W. 2010. The terrestrial natural communities of Missouri. Jefferson City: Missouri Natural Areas Committee.

Nicholson, S.W., C.L. Dicken, J.D. Horton, K.A. Labay, M.P. Foose, and J.A.L. Mueller. 2005. Preliminary integrated geologic map databases for the United States. Kentucky, Ohio, Tennessee, and West Virginia: U.S. Geological Survey, OpenFile Report OF-2005-1324, scale 1:250,000 https://doi.org/10.3133/ ofr20051324.

Nielsen, S., C. Kirschbaum, and A. Haney. 2003. Restoration of Midwest oak barrens: structural manipulation or process-only? Conservation Ecology 7: 10 https://doi.org/10.5751/ES-00536-070210.

Noss, R. F., E. T. LaRoe, III, and J. M. Scott. 1995. Endangered ecosystems of the United States: a preliminary assessment of loss and degradation. U S Fish and Wildlife Service Biological Report 28: i-iv, 1-58.

Nowacki, G.J., and M.D. Abrams. 2008. The demise of fire and "mesophication" of forests in the Eastern United States. BioScience 58: 123-138 https://doi.org/10. 1641/B580207.

Nowacki, G.J., and M.D. Abrams. 2015. Is climate an important driver of postEuropean vegetation change in the Eastern United States? Global Change Biology 21: 314-334 https://doi.org/10.1111/gcb.12663.

Nuzzo, V.A. 1986. Extent and status of Midwest USA oak savanna presettlement and 1985. Natural Areas Journal 6: 6-36.

Peterson, D.W., and P.B. Reich. 2001. Prescribed fire in oak savanna: fire frequency effects on stand structure and dynamics. Ecological Applications 11: 914-927 https://doi.org/10.1890/1051-0761(2001)011[0914:PFIOSF]2.0.CO;2.

Peterson, D.W., and P.B. Reich. 2008. Fire frequency and tree canopy structure influence plant species diversity in a forest-grassland ecotone. Plant Ecology 194: 5-16 https://doi.org/10.1007/s11258-007-9270-4.

Peterson, D.W., P.B. Reich, and K.J. Wrage. 2007. Plant functional group responses to fire frequency and tree canopy cover gradients in oak savannas and woodlands. Journal of Vegetation Science 18: 3-12 https://doi.org/10.1111/j. 1654-1103.2007.tb02510.x.

Ramsey, J.G.M. 1853. The annals of Tennessee to the end of the eighteenth century, 743. Charleston: Steam Power Press of Walker and James.

Robertson, K.M., and T.L. Hmielowski. 2014. Effects of fire frequency and season on resprouting of woody plants in Southeastern US pine-grassland communities. Oecologia 174: 765-776 https://doi.org/10.1007/s00442-013-2823-4.

Scharenbroch, B.C., B. Nix, K.A. Jacobs, and M.L. Bowles. 2012. Two decades of low-severity prescribed fire increases soil nutrient availability in a Midwestern, USA oak (Quercus) forest. Geoderma 183: 80-91 https://doi.org/10.1016/j. geoderma.2012.03.010

Shapiro, S.S., and M.B. Wilk. 1965. An analysis of variance test for normality (complete samples). Biometrika 52: 591-611 https://doi.org/10.1093/biomet/52.3-4.591.

Soil Survey Staff Natural Resources Conservation Service. 2014. United States Department of Agriculture, Web Soil Survey. http://websoilsurvey.nrcs.usda. gov/. Accessed 20 Feb 2014

Stambaugh, M.C., J.M. Varner, R.F. Noss, D.C. Dey, N.L. Christensen, R.F. Baldwin, R.P. Guyette, B.B. Hanberry, C.A. Harper, S.G. Lindblom, and T.A. Waldrop. 2015. Clarifying the role of fire in the deciduous forests of eastern North America: reply to Matlack. Conservation Biology 29: 942-946 https://doi.org/10.1111/cobi.12473.

Taft, J.B. 1997. Savanna and open-woodland communities. In: Conservation in highly fragmented landscapes, ed. M.W. Schwartz, 24-54. Chicago: Chapman and Hall https://doi.org/10.1007/978-1-4757-0656-7_2 .
Vander Yacht, A.L., P.D. Keyser, C. Kwit, M.C. Stambaugh, W.K. Clatterbuck, and D. M. Simon. 2019. Fuel dynamics during oak woodland and savanna restoration in the Mid-South USA. International Journal of Wildland Fire 28: 70-84 https://doi.org/10.1071/WF18048.

Vander Yacht, A.L., S.A. Barrioz, P.D. Keyser, C.A. Harper, D.S. Buckley, D.A. Buehler, and R. D. Applegate. 2017a. Vegetation response to canopy disturbance and season of burn during oak woodland and savanna restoration in Tennessee. Forest Ecology and Management 390: 187-202 https://doi.org/10.1016/j.foreco.2017.01.029.

Vander Yacht, A.L., P.D. Keyser, D.A. Buehler, C.A. Harper, D.S. Buckley, and R.D. Applegate. 2016. Avian occupancy response to oak woodland and savanna restoration. The Journal of Wildlife Management 80: 1091-1105 https://doi.org/ 10.1002/jwmg.21097.

Vander Yacht, A.L., P.D. Keyser, C.A. Harper, D.S. Buckley, and A.M. Saxton. 2017b. Restoration of oak woodlands and savannas in Tennessee using canopydisturbance, fire-season, and herbicides. Forest Ecology and Management 406: 351-360 https://doi.org/10.1016/j.foreco.2017.07.031.

Vose, J.M., and K.J. Elliott. 2016. Oak, fire, and global change in the Eastern USA: What might the future hold? Fire Ecology 12: 160-179 https://doi.org/10. 4996/fireecology.1202160

Waldrop, T.A., D.L. White, and S.M. Jones. 1992. Fire regimes for pine grassland communities in the Southeastern United States. Forest Ecology and Management 47: 195-210 https://doi.org/10.1016/0378-1127(92)90274-D.

\section{Publisher's Note}

Springer Nature remains neutral with regard to jurisdictional claims in published maps and institutional affiliations.

\section{Submit your manuscript to a SpringerOpen ${ }^{\circ}$ journal and benefit from:}

- Convenient online submission

- Rigorous peer review

- Open access: articles freely available online

High visibility within the field

- Retaining the copyright to your article

Submit your next manuscript at $\boldsymbol{\nabla}$ springeropen.com 